

\title{
EL HISPANO TEODOSIO Y LA CRISTIANIZACIÓN DEL IMPERIO
}

\author{
POR \\ FLORENCIO HÜBEÑÁx \\ Universidad Católica Argentina, Buenos Aires
}

\section{RESUMEN}

El autor analiza un tema de enorme trascendencia: la relación del imperio romano con el cristianismo. Dentro de esta temática la figura del emperador Teadosio es fundamental, ya que cimentó un nuevo orden europeo integrando herejes, paganos y «bárbaros».

\section{Abstract}

A topic of enormon transcendentality is analyzed by the author: the relation of roman empire and cristianism. In this topic figure of emperor teodosius is fundamental, because a new european equilibrium was readred, integraling heretics, pagans and «barbanians».

\section{ASPECTOS INTRODUCTORIOS.}

Uno de los temas más importantes del siglo IV —escasamente analizado por los romanistas - es la relación del Imperio romano con el cristianismo. Una gran mayoría de historiadores ha sostenido la simplificada tesis que fue Constantino quien cristianizó al Imperio.

No es nuestra intención, en este trabajo, analizar dicho tema, sino rescatar el papel que le cupo al basileus Teodosio. Para ello debemos revisar algunas ideas de esta cuestión. 
El análisis de la relación de Constantino con el cristianismo se inicia con la visión de la víspera de la batalla del puente Milvio y con la circular conocida como edicto de Milán, pero debemos añadir que este emperador contó, desde los comienzos de su actividad pública, con el consejo del obispo hispano Osio para las cuestiones dogmáticas y del obispo -e historiador- Eusebio de Cesarea para las concepciones políticas.

En nuestra opinión Constantino - y sus consejeros-, más allá de las razones personales que llevaron a su conversión en el lecho de muerte, apreció con claridad el proceso de disgregación del Imperio romano por la pérdida de la "mística política» que le servía de sustento' y consideró que uno de los caminos de «salvación» - si no el único- consistía en incorporar el cristianismo y convertirlo en esa mística faltante. Más allá de su discutida «ortodoxia religiosa» a ello parecen apuntar algunas de sus medidas concretas, como también a justificarla se dirige la nueva teoría política imperial que elaboró Eusebio de Cesarea y que seguira el basileus y sus sucesores, fundamentalmente en Constantinopla.

Para esta concepción política imperial -o mejor teológico-política ${ }^{2}$ - elaborada por Eusebio de Cesarea, Constantino, el basileus era el Kosmos-krator o emperador que actuaba -al mejor estilo neoplatónico y estoico que detallara Dion de Prusa - como el representante de la Divinidad cósmica que administraba de manera vicaria el orden político (basileia luego imperium) en la tierra (el orbis terrarum) a la manera como el Verbo Encarnado administraba la Creación ${ }^{3}$. El mismo Eusebio lo expresará públicamente en el panegírico que pronunciará con motivo de los treinta años de reinado del emperador, al afirmar: «No existe sino un único Rey celestial y su único Logos y Nomos real que no se puede explicitar por palabras y sílabas y que no hace perder tiempo en escritos y estelas para designarlo» ${ }^{4}$. Una vez más - al mejor estilo romano tradicional- en Eusebio se reencontraban política y religión ${ }^{5}$. Encontramos

1 La Roma eterna augustea, la concepción Imperial estoica, la «teología solam, de la dinastía siria, el pragmatismo de Dioclesiano. Cfr. HUBEN̂ÁK, Florencio. Roma. EJ alto político, Bs. AS., Ciudad Argentina, 1997; TURCAN, Robert. Le culta Imperial au III siecle, en: A.N.D.R.W., 1972, 11, 16,2 , p. $996 / 1084$.

2 Cfr. FARINA, Raffaele. L'Impero a l'Imperatore cristiano In Eurebi.o di Cesarea. La prima teologia politica del Cristianismo. Zurich, Pas Verlag, 1966 y CRANZ, F. Edward. «Kingdon and Polity In Eusebius of Caesarea», en: Harvard Theological Review, 45, 1952, p. 47/66.

${ }^{3}$ Cfr. EUSEBIO. Vita Constantini. 11, 19, 1/2 y IV, 29, 1/4.

4 Díscurso-panegírico del triakontaétérikos de Constantino el 25 de julio del 336.

${ }^{5}$ Cfr. HUBENÁK, Florencio. Roma. El mito polttico citada, espec. págs. 213/53 y «Historia política y profecfa. Roma y los grandes imperios antiguos a la luz de las predicciones del profeta Daniels, en: Hispania Sacra, 48, enero-junio 1996, p. 95/119.

Hispania del Mediterráneo al Atlántico

Hispania Sacra 51 (1999) 
similares fundamentaciones en el llamado edicto de Milán, que concluye con las persecuciones y proclama la licitud del cristianismo ${ }^{6}$.

Por ello, en nuestra opinión, la jdea clave de esta teoría política consiste en garantizar la nueva pax augustea, ahora pax christiana, basada fundamentalmente en la unidad política y religiosa (la homonoia helenística), ya que ella es la garantía de la renovatio imperial del novo saeculum que se anuncia. Así lo señala el propio Constantino en una carta dirigida al prefecto Elafio ese mismo año 313, al afirmar: «Yo considero que no está bien de ningún modo el que las contiendas o altercados me sean ocultados, pues como consecuencia de ello la Divinidad puede sentirse impelida no sólo en contra de la raza humana, sino también contra mí, a cuyo cuidado El ha confiado por su celestial decreto la dirección de todos los asuntos humanos, de modo que, montando en cólera, pueda decretar contrariamente a cómo lo ha hecho hasta ahora. Luego, creo que podré esperar realmente y en el mayor grado posible verme libre de ansiedad y alentar a la vez esperanzas del mejor, más favorable y siempre dispuesto apoyo del muy poderoso Dios, cuando vea que todos los hombres unidos, en fraternal armonía están adorando al muy santo Dios, en el culto de la religión católica, que es legítimamente suya»?

Pero prontamente queda demostrado que para el cumplimiento de estos objetivos no alcanzaba con la integración del cristianismo a la estructura imperial, ya que ella provocará la reacción del tradicional ordo senatorial de la ciudad de Roma, el comienzo de las divergencias internas dentro del propio cristianismo -la aparición de las herejías-m y finalmente, la presión cada vez mayor de los pueblos godos sobre las fronteras del Imperio.

Los problemas superarán con creces la habilidad de Constantino, quien se enemistará con la elite dirigente romana fundando la Nea Roma, luego Constántinopla, en el 326 y tratará de lograr la unidad religiosa en lo dogmático - aconsejado por su amigo el obispo Osio de Córdoba- mediante la convocatoria del concilio de Nicea, que, en el 325 (?), definió el credo cristiano. Las respuestas llegarán solo medio siglo después, con el emperador Teodosio.

Conviene recordar que Constantino dividió el gobierno del Imperio entre sus tres hijos Constantino II, Constante y Constancio, quienes pelearon entre sí y fueron sucesivamente derrotados hasta que, tras la muerte de Constancio, - el último- bajo quien según San Jerónimo «el universo gimió de verse arriano», accedio al Imperio, en el 361, su «sobrino» Juliano, apodado «el apóstata», quien intentó revertir el avance del cristianismo y rescatar una «teología neo-

6 Cfr. Lactancio. De la muerte de los perseguidores. XIVIII. Cfr. Eusebio Historia eclesidstica. $\mathrm{m}, 5,4 / 14$.

7 Cit. HolsAPPLE, Lloyd B. Constantino el grande. Bs.As., Espasa Calpe, 1947, p. 186. 
helenística». Su temprana derrota y muerte ante los persas llevó a la sede imperial a Joviano y a los pocos meses, al sorpresivo deceso de éste, en el 364 a Valentiniano I (Valentinianus). Así se originó una nueva dinastía, favorable al cristianismo. Presionado por sus tropas y oficiales designo colega a su hermano Valente (Valens), asignándole como sede Constantinopla. En el 375, la muerte de Valentiniano I, llevó a la designación de sus hijos Graciano (Flavius Gratianus), de dieciséis años de edad, y Valentiniano II, de solo cuatro ${ }^{8}$.

La presión de los pueblos godos que, empujados por los hunos, habían irrumpido en los lindes del Imperio llevó a Valente, en un rapto de impulsividad, a atacarles sin esperar la ayuda de su sobrino Graciano y fue trágicamente derrotado y muerto en la batalla de Adrianápolis, en el 378 , produciendo una de las crisis más graves del período de decadencia del Imperio romano, que llevó al obispo Ambrosio de Milán a horrorizarse y exclamar «Estamos vìviendo el ocaso del mundo»?.

En estas circunstancias críticas el emperador Graciano y sus consejeros apreciaron la necesidad de designar un colega militar experimentado y capacitado para rehacer las legiones y asegurar la defensa del Imperio; eligió al hispano Teodosio y le confió el gobierno de la pars orientalis. Pero quien era Teodosio?

\section{TEODOSIO}

Teodosio (Flavius Theodosius) fue designado emperador (imperator o basileus) el 19 de enero del $379^{10}$, tras varios meses de vacancia con motivo de la tragica muerte de Valente. Tenía entonces alrededor de treinta y tres años de edad y había nacido en Cauca ${ }^{11}$.

\footnotetext{
8 Cfr. HUBEÑÁ, Florencio. «El emperador Graciano en el pasaje de la Romanidad a la Cristiandad». Stylos, 1998, (en prensa).

${ }^{9}$ Exposit. Evang. s. Lucam 10, 10.

10 Chron. Min. I, 243 y 297. La fecha es mencionada por S6crates. Historia ecclesiastica. V, 2. Elegido por el Senado según Malalas. Chronica. XIII, 344; reconocido por el Senado según Pacatus. VII y también Themist. Oratio. XIV.

11 Actual Coca, bajo la sierra de Guadarrama, en la provincia de Segovia (cerca de Valladolid). Pacato en su panegírico del 389 escribe «Hispania nos ha dado el Dios que podemos ver» (cit. TEJA Ramon. «Un emperador hispano para Roma», en: Historia'16. XXI, 249, enero 1997, p. 37), el 11 de enero del 346 Zosino. Nueva historia. IV, 24, 7. Tuvo dos hermanos: Honorio (muerto antes de ascender éste al trono y cuyas hijas adoptó y cuidó. Termancia fue casada con un oficial del Imperio y Serena con el vándalo Stilicón) y una mujer cuyo nombre desconocemos. Sobre Serena sabernos que «Teodosio había adoptado a Serena cuando murió su padre y la hizo llevar a la corte de Constantinopla, donde recibió una refinada cultura clásica y cristiana. Escogío para ella un marido adecuado (Stilicón) y cuando murió la emperatriz Flaccila (a. 386) le confió la regencia de su hijo Honorio.
} 
Según Claudiano «la familia descendía de la familia Ulpia» o sea de Traiano ${ }^{12}$, aunque solo sabemos con certeza que pertenecía a una gran familia hispano-romana de religión cristiana.

Su padre ${ }^{13}$ fue un hábil militar y rico terrateniente - de origen hispano, de la provincia de Galaecia, casado con Termancía - que ascendió velozmente bajo Valentiniano I, fue comes domesticorum en Britannia y venció a los alamanes ${ }^{14}$. Convertido en el militar más importante de su tiempo fue designado magister equitum y en el 373 reprimió las revueltas del moro Firmus ${ }^{15}$ y de los circumcelliones en el norte del Africa convulsionada por las crisis economico-sociales y el movimiento donatista.

Paralelamente sus aliados «hispanos» ingresaron en la corte imperial hacia el 376, al igual que su hijo ${ }^{16}$. Quizás envidiado por tantos éxitos, fue condenado de manera sumaria y decapitado en Cartago, a principio del año 376 , a los 55 años de edad, por orden del propio Valentiniano I o de su hijo y sucesor Graciano, tal vez por la creciente influencia de Merobaudo, víctima de una conjura palaciega cuyos motivos y actores principales se nos escapan ${ }^{17}$.

Claudiano proclamaba que Teodosio y Serena hablan conpartido una Intimidad única. Ella ejercía sobre él, un hombre de temperamento inestable y propenso a los ataques de ira, como demostraría en muchos actos de su gobierno, una influencia mayor que cualquier otro miembro de su entorno, Incluida, la emperatriz: "cada vez que, oprimido por el peso del cargo público, volvía a casa abatido o henchido de una ira irreprimible, mientras los hijos se quitaban de la vista del padre e incluso Flaccila tenf́a al esposo airado, tu eras la única capaz de calmar su indignación y tranquilizarle con tus dulces palabras. El bebía de sus labios, a ti confiaba sus secretos" [...] (Laus Serenae. 135/139)» (MARCOS, Mar. "Como crear una dinastía: Teodosio y su familia", en: Historia 16, XXI, 249, enero, 1997, p. 47).

12 N Consulado de Honorio. Poemas. Madrid, Gredos, 1993, t. I, p. 204. Similar opinión en el panegírico de Temistio; no así en Pacato.«Su nomen, Flavius, el mismo de su padre, perece reflejar que sus antepasados, indígenas peninsulares, habían recibido la ciudadanía romana en el siglo I con el emperador Flavius Vespasianus. Su cognomen, Theodosius indica la condición cristiana de la familia. Lo era ya su padre, aunque no se bautiz6 hasta momentos antes de ser ejecutado en el 375 en Cartago» (TejA, Ramón. «Un emperador hispano para Roma», en: Historia 16. XXI, 249, enero 1997, p. 38).

${ }^{13}$ De su madre apenas si conocemos su nombre Termancia «Epit. de Caes.48». Cfr. Marcos cit., p. 54.

14 A partir de esa victoria una colonia de ellos fue establecida en la llanura padana en tierras donadas por el emperador y que cultivaban como tributarios. Parece ser un antecedente de la política de su hijo con los «bárbaros».

15 Cfr. STEIN, Emest. Histoire du Bas Empire. Paris, Desclée de Brouwer, 1959, t. I, p. 179.

16 Cfr. GulJarro, Andrés. «Perfiles de una familia de la aristocracia hispanorronana», en: Retigión y cultura, XI, 1994, p. 358.

17 GARCÍA MORENO, Luis A. La Antigüedad clásica, en: Historia universal. Pamplona, EUNSA, 1985, T.1 1, 2, p. 411 . Según Paulo Orosio «se le condenó a muerte por maquinaciones de la envidia; se hizo bautizar en Cartago para perdón de sus pecados y después de recibir el Sacramento de Cristo, que deseaba, después de una vida gloriosa en el siglo, seguro de la vida eterna, presentó de buen grado el cuello al verdugon (Paulo Orosio. Historia contra paganos. XXXIII, 7). 
En 376, Teodosio, se casó con Elia Flavia Flaccilla, hija de Flavius Claudius Antonius, personaje en la corte de Graciano y prefecto del pretorio en las Galias entre el 376 y $378^{18}$.

La muerte de su padre, presuntamente víctima de un complot, le sorprendió - a los 27 años- combatiendo como dux en la Moesia, y temeroso por su propia vida, se retiró a sus posesiones en Hispania para atenderias como «terrateniente» (soldado-agricultor) ${ }^{19}$ y estudiar los clásicos, especialmente históricos» ${ }^{20}$.

Allí intentó permanecer inadvertido «para evitar los dardos de la envidia». como dice Teodoreto de Ciro» ${ }^{21}$ durante dos años hasta que le convocó el emperador Graciano después de la derrota de Adrianópolis y nombrándole magister equitum partió a las orillas del Danubio para combatir a los invasores sármatas $^{22}$, que presionados quizás por los visigodos de Athanaric, habían cruzado el Danubio; allí obtuvo una importante victoria a fines del 378 , que favoreció su candidatura imperial ${ }^{23}$.

En su sorpresiva eleccion se deben incluir varios factores: el citado antecedente militar de su padre ajusticiado injustamente, su propia capacidad militar adquirida combatiendo junto a él y, fundamentalmente, sus amigos que habían accedido a la Corte en el 376. Al tratar de encontrar una razón para que Graciano le eligiera como colega los historiadores agregan al remordimiento, la presión militar por las simpatías que gozaba en las legiones como la eclesiástica

${ }^{18}$ Con ella tuvo tres hijos: Arcadio (Arcadius) (nacido en Cauce en el 377), Pulqueria (nacida en el 378 y muerta a los seis años de edad) y Honorio (Honorius) (nacido en Constantinopla). Con su segunda esposa (Gala) tuvo tres hijos pero solo sobrevivió la hermosa Gala Placidia. Afectada por la muerte de su hija, la emperatriz Flaccila murió el 14 de agosto del mismo affo de aquella, dejando hijos de 8 y 1 ańos de edad. «Teodosio y su familia fueron siempre conscientes de lo extraordinario de su suerte, y algunos autores modernos han interpretado la orientación de la política religiosa del emperador como una consecuencia del impacto que debió producir en su espíritu este repentino cambio de fortuna. La emperatriz Flaccila, una mujer comprometida con el credo niceno y muy intransigente en cuestiones de política religiosa, se lo recordaba a veces: "Esposo mío, debes acordarte siempre de lo que fuiste una vez y en lo que te has convertido; teniendo esto presente siempre no te mostrarás nunca desagradecido con tu benefactor y gobernarás conforme a la ley el imperio que te ha sido otorgado y le rezarás a El que te lo dio" (Teodoreto de Ciro. H.E. 18) (MARCos, Mar. cit., p. 48/50). Teodoreto de Ciro escribe que Flaccila solía decir con frecuencia: «Esposo, recuerda siempre lo que fuiste en otro tiempo y lo que eres ahora... pues si lo recuerdas no serás ingrato a aquellos de quienes recibiste el Imperio y gobernarás con buenas leyes» (Teodoreto. Historia de la Iglesia. v, 19. cit. Guijarro, Andrés. Perfiles... p. 357).

19 «Como olvidabas la vida urbana para hacerte agricultors (Pacato. Panegirico. DX).

20 Cfr. Claudiano. Elogio de Serena. Madtid, Gredos, 1993, t. 11, p. 222 y Prudencio. Contra Símaco. I, 35/37.

${ }^{21}$ GUIJARRO cit. p. 356.

22 Piganiol sugiere que su victoria ha sido exagerada y convertida en leyenda (PIGANIOL, André. L'Enpire chrétien. París, Presses Universitaires de France, 1947, p. 208).

${ }^{23}$ Cfr. STEIN, E. op. cit., t. I, p. 191.

Hispania, del Mediterráneo al Atlántico

Hispania Sacra 51 (1999) 
del hispano Dámaso —entonces obispo de Roma-, los intereses de la aristocracia hispano-aquitana y aún la influencia del obispo Ambrosio de Milán ${ }^{24}$.

Bien observa Teja que «resulta evidente que a partir de la elección de Teodosio, será este emperador quien lleve la primacía de la política imperial apareciendo Graciano casi como una comparsa. La mayor personalidad de Teodosio y el creciente predominio económico y peso político del Oriente respecto a Occidente, así como la mayor gravedad de los problemas de Oriente a raíz del desastre de Adrianópolis, son los factores más determinantes» ${ }^{25}$.

\section{SUS PRIMERAS MEDIDAS: LOS GODOS.}

Apenas llegó al poder, Teodosio encaró el problema más grave que aquejaba al Imperio en crisis: la caótica situación militar producida con motivo de la derrota de Adrianopolis, que había abierto una brecha en el eficaz sistema de defensas organizado por Valentiniano I y permitido la entrada de una avalancha de «bárbaros». Sobre esta cuestión nos limitaremos a señalar -en el aspecto que nos interesa: la paz y la unidad de Roma- que Teodosio dedicó sus primeros esfuerzos a reconstruir las legiones -basamento del Imperio-reorganizando un sistema de reclutamiento de ciudadanos romanos - no extranjeros- para obtener nuevas tropas que compensaran las pérdidas de Adrianópolis, a la vez que lentamente reemplazó la infantería - allí superada - por una caballería integrada por tropas de experimentados jinetes godos ${ }^{26}$. Al efectuar las levas se tomaron medidas para que «nadie pudiera substraerse a la curia; ya ni la línea de batalla servía de refugio al acosado contribuyente. Una disposición anterior había ya llamado a todos los curiales a su funciones hereditarias, aunque hubiesen conseguido «meterse» en las hileras del Senado o en las de la

\footnotetext{
24 Paribeni acentúa el consejo del obispo Ambrosio de Milán, ya que cuando Teodosio fue dux de Mesia, Ambrosio estaba adscripto a la prefectura del Ilírico (PARIBENI, Roberto. Da Diocleziano alla caduta dell'Impero d'Occidente. Bologna, Capelli, 1941, p. 167/8). Malalas. (Chron. p. 344) atribuye la idea de la eleccí́n de Teodosio a un tal hulius del que también hablaría Zosimo. IV, 26; Seek babla de la influencia de su tío Eucherius idéntico al conde de generosidades sacras del 377 (?) y de su bello-hermano Syagrius según PIGANIOL, A. op. cit., p. 209, nota 56. \&La hipótesis más reciente ha sido expuesta en el Congreso Internacional sobre Teodosio, celebrado en Segovia en octubre de 1995, por la historiadora Italiana Rita Lizzi. Haciendo uso de una gran erudición esta estudiosa ha Intentado descubrir en Oriente una coalicion de influyentes políticos, militares y obispos, entre los que estaria el propio san Gregorio de Nacianzo, quienes habrían sido los que forzaron la llamada de Teodosio, a quien conocían bien pot sus anteriores actuaciones en Oriente...» (TEJA, Ramon. «Un emperador hispano para Roma», en: Historia 16. XXI, 249, enero 1997, p. 39).

25 TEJA, Ramón. La épaca de los Valentinianos y de Teodosio, en Historia del mundo antizuo. Madrid, AKAL, 1991, p. 42.

${ }^{26}$ Cfr. Zósimo. IV, 30.
} 
burocracia ${ }^{27}$. Tal orden fue reiterada en sucesivas ocasiones durante los siguientes años (382 y 383). En el 383, las exenciones, antes concedidas a los rabinos judios fueron rescindidas; y las personas deseosas de ingresar en el ministerio cristiano sólo quedaban autorizadas para ello si hallaban sustituto que asumiera sus obligaciones fiscales ${ }^{28}$.

En el fatídíco año 379 los rex godos retornaron al plan estratégico que habían comenzado el año anterior y empujados y seguidos por alanos y hunos invadieron el sur de la península balcánica (el Epiro, la Tesalia y Grecia septentrional) y al año siguiente los visigodos «cristianizados» guiados por Fritigerno ocuparon el sur de la Macedonia mientras que las hordas conducidas por Alatheus y Saphrax avanzaban sobre la Nórica y la Pannonia. Libanio (Libanius) afirmaba que todo era saqueado en las ciudades y que se morían de hambre ${ }^{29}$ y Juan de Stridón, el crisóstomo, refería que los bárbaros avanzaban danzando más que combatiendo: un jefe bárbaro, fatigado de matar, decía que no comprendía porqué los romanos no huían en lugar de ofrecerse a la masacre (I, 344 c.d.) $)^{30}$.

Teodosio, que se reponía de una grave enfermedad como consecuencia de una peste que había invadido toda la región ${ }^{31}$, no pudo llevar a la práctica el plan defensivo combinado con su colega y debió presenciar la derrota que le infringió Fritigemo y el pillaje de toda la diócesis de Macedonia. El propio emperador acudió al campo, pero fue rodeado y debió huir para evitar ser capturado $^{32}$.

Por ello debió recurrir a la diplomacia negociando con el godo «pagano» Atanarico (Athanaric) - enemigo de Fritigerno- que con nuevas hordas invadiera la península, hasta tanto llegara la ayuda solicitada a su colega Graciano. Con éste, que le envió refuerzos al mando de los francos Baután (o Baudo) y Arbogasto (Arbogastes), se encontraron en Sirmio a finales del verano ${ }^{33}$. Graciano concluyo un tratado de paz con Alatheus y Sarphax, por el cual les

${ }^{27}$ Cod. Theod. XII, 1,82 del 22 de abril del 380.

28 Cod. Theod. XII, 1, 111, 113 y 114 del 386.

${ }^{29}$ Oratio. XXIV, 15.

30 PIGANIOL, A. op. cit., P. 211/2.

31 En dicha ocasión fue bautizado en Tesalónica (Thessatoniki, hoy Saloniki -Salónica- en Grecia) por el obispo Acholius (Sozomeno. Historia Ecclesiastica. VII, 4), probablemente en diciembre del 380. Tillemont fija la enfermedad entre el 2 y el 27 de febrero del 380 para explicar el edicto religioso del 27 de febrero; Seeck (Geschicte), Palanque e Higgins lo fechan en diciembre del 379; Seeck (Regesten) lo data en el otofio del 380, fecha que comparte Piganiol interpretando las fuentes: Zosino IV, 34, Jordanes. XXVII, Próspero a. 380. (cit. PIGANIOL, A. op.cit. p. 212, nota 80).

32 Zosino IV. 31: Jordanes. Rerun gothorum. XXVII; 149.

33 Allí habrian resuelto la convocatoria del concilio universal de Constantinopla, como también las características de las operaciones militares y la paz con los godos; presumiblemente una «retirada estratégica» en Pannonia y la Thracia como sugiere Piganiol, A. op. cit., p. 223. 
atorgó el derecho a instalarse en ciertas partes de la Pannonia como federados del Imperio en noviembre del $380^{34}$.

Después Teodosio hizo su primera entrada triunfal en su sede - Constantinopla - para festejar con gran pompa el fin de las luchas ${ }^{35}$. Allí en el otoño negocio con el rex Atanarico ${ }^{36}$, el universae gentis Gothoruim rex, firmó el tratado del $2 / 3$ de octubre del $382^{37}$, por el cual se convirtieron en foederati del Imperio. Esto significaba que los godos, instalados dentro de los limes del Imperio, formaban una nación autónoma, cuyas relaciones se regulaban expresamente por un foedus que reemplazaba tierras y alimentación por ayuda militar -especialmente caballería - contra nuevos «bárbaros», preludiando el vasallaje feudal. «Con ello se daba nacimiento al primer Estado germánico libre en el interior del Imperio ${ }^{38}$. «Reunidos allí en aldeas los godos conservaron su idioma, sus usos y su tosca libertad, reconociendo la supremacía del emperador; pero no quisieron aceptar las leyes ni la jurisdicción de los magistrados del imperio. Ya no tuvieron más reyes y mandaron tanto en paz como en guerra los jefes de las tribus y de las familias. El contingente que suministraban al ejército para servir a las órdenes de generales escogidos por el emperador, era de $\mathbf{4 0 . 0 0 0}$ auxiliares, bajo el nombre de federados, distinguidos por collares de oro, y disfrutando de una pingüe paga y de grandes privilegios» ${ }^{39}$.

${ }^{34}$ Según Zosimo IV, 34, 1/2 y Jordanes XXVII, 141. Cfr. Stein, E. op. cit., t.I, p. 193. Piganiol señala que el asentamiento no es ninguna novedad pues ya Constancio Cloro había instalado francos salios en la Isla de los bátavos entre el Lek y el waal y Jullano luego los trasladó entre Brabante y Llimburg (Piganiol, A. op. cit., p. 223).

${ }^{35}$ El 24 de noviembre del 380 (s/ DEMOUGEOT, op.cit. P. 149 y el 11 de enero del 381 (s/ Candau p. 373 y Paredi, op cit. p. 265) negocia con el rex Atanarico en Constantinopla).

36 Según Jordanes venía de suceder a Fritigerno que había sido muerto o destituído (XXVIII, 142) Jordanes (XXVIII, 1,42) afirma que fue invitado por Teodosio, mientras que Zosimo (IV, 34, 3) y Themístios XV, 190/191 lo hacen ir por su cuenta y según el primero «suplicante». Demougeot sef̃ala que ues muy probable que Atanarico no vino a Constantinopla con todo su pueblo, sino solamente con una importante escolta, sus comitatus, y que pocos vísigodos habían cruzado a la orilla romana con Alavivus Fritigerno en 376" (Demougeot, Emilienne. La formation de I'Europe et les Invasions barbares. París, Aubier, 1979, t. II, p. 151). Recién más tarde, perseguimos por los hunos y ostrogodos -como señala Zosimo (IV, 34, 6)- y diseminados en bandas a la muerte de su candillo Fritigeno pidieron a Teodosio pasar a la orilla romana. Como consecuencia de «laboriosas negociaciones» el sucesor de Atanarico [Atanarico murí al poco tiempo de haber estado en Constantinopla, probablemente el 25 de enero del 381 segun Piganiol (op. cit., p. 213) y se le hicieron magníficos funerales que halagaron el orgullo de los godos (Cfr. Chron. Min. I, 243 y 461 y Zosimo IV, 34, 3-5) $y$ «todas las tribus de godas, a la muerte de su rex, admirando la valentla y benignidad de Teodosio, se entregaron al Imperion (Orosio XXXIV, 7).

${ }^{77}$ La fecha figura en la cronica de Hidacio y fue logrado gracias a las alaboriosas negociaciones llevadas a cabo por Saturninus, un anciano y humanista general de Valente, amigo del rethor Libanios.

38 GARCIA MORENO, L. op. cit., t.II, 2, P. 416.

${ }^{39}$ CANTú, César. Historia universal. Barcelona, Cassó, 1911, t. XI, p. 184]. op. cit., XI, p. 203. 
Así se inició una política sistemática de integración de «bárbaros» en el Imperio, cuyo primer paso consistía en sedentarizarlos.

Esta política - hoy criticada - tuvo grandes defensores en su época; en ocasion del cambio de cónsules del $1^{\circ}$ de enero del 383 Themistios pronunció un panegírico elogiándola en estos términos: «Este nombre odiado de Gódos, vos como lo hiciste ser amado... Es una victoria de la filantropía, no más suprimirlos, sino convertirlos en mejores... Vale más lienar la Thracia de cadáveres que de campesinos?... Aquellos que vienen de abajo dicen que con el hierro de las espadas y de las corazas ellos harán arados y hoces ${ }^{40}$. En todo momento se nota no sólo la desesperación por la seguridad inmediata del Imperio sino, más allá, la búsqueda de la integración que garantice la unidad de la Romanidad. Este aspecto del proceso que caracterizará el pasaje de la Romanidad a la Cristiandad en ese siglo y el siguiente se aprecia en la preocupación por la cristianización y romanización de los «bárbaros» ${ }^{4 t}$.

Hoy resulta evidente que los resultados fueron buenos, ya que salvo dos breves períodos de guerra sin importancia $(421-422$; 441), la paz duro hasta el 502. «Esta seguridad es de una importancia capital: Constantinopla ha podido desviar hacia otros lugares las amenazas de los germanos y de los hunos» ${ }^{42}$.

\section{LAS MEDIDAS CONTRA LOS HEREJES.}

Teodosio ha pasado a la historia como el emperador que convirtió al cristianismo en la religión oficial del Imperio romano, integrando a sus funcionarios - los obispos - al aparato estatal a fin de reforzar y salvaguardar a éste, aún comprometiéndolo con el estado mismo ${ }^{43}$.

Una vez adoptadas las medidas más urgentes frente al primer obstáculo contra su política de unidad (los godos), Teodosio pudo dedicar sus esfuerzos a las cuestiones estrictamente religiosas.

Para entender la importancia del tema es necesario destacar que los rumores y las discusiones callejeras crean la «atmósfera» de una época; hoy éstas están dedicadas a deportistas, y estrellas, pero en el siglo $\mathrm{V}$ existía otra sensibilidad

\footnotetext{
40 Oratio XVI. cit. Piganiol, A. op.cit., p. 214

41 Por otra parte sabemos que «los godos amaban a Teodosio como si su conducta fuera hija del afecto que les profesaba (amator pacius generisque Gotorhum) (Jordanes XXIX).

42 RÉMONDON, Roger. La crisis del Imperio romano. Barcelona, Labor, 1973, p. 109.

43 La historiografía de la Iglesia le otorgara luego el título de Grande. Según Marique (Then Co mes Theodosius. A Prosography, en: Classical Folia, XVI, 1962, 1, p. 22), en cambio, el título de «grande» fue usado por vez primera por Edward Gibbon en su renombrado trabajo sobre la decadencia del Imperio Romano.
} 
religiosa y la gente se apasionaba por las cuestiones teológicas. A manera de ejemplo Gregorio de Nisa nos menciona «al cambista que, si se le pregunta por el valor de una moneda, responde con una disertación sobre el Engendrado y el no Engendrado; entráis en casa del panadero; el Padre, os dice, es mayor que el Hijo; en las termas preguntáis si el baño está preparado: se os replica que el Hijo ha nacido de la nada ${ }^{44}$.

Teodosio al trasladarse a la pars orientalis pudo comprobar personalmente las graves divergencias que se producían entre cristianos y «paganos», arrianos o nicenos y aún cristianos, paganos o judíos, como también observar que uno de los aspectos que agravaba las disputas religiosas era la «atmósfera» del Oriente, más afín a las discusiones racionalistas griegas que acentuaban $-y$ hacían casi permanentes- las disputas religiosas.

Como señalaremos anteriormente, una vez convertido el cristianismo en la religión oficial del Imperio, la necesidad de profundizar en la afinación de las creencias (dogmas) provocó divergencias internas en la comunidad eclesiástica conocidas coma herejías, las que atentaban contra la unidad religiosa y, por extensión, socio-política. Evidentemente para los emperadores, ansiosos en lograr y preservar la unidad, el Dios de los cristianos era uno solo y no podía ser entendido más que de una sola manera, aquella en que lo entendía la Iglesia institucionalizada e incorporada a la estructura del Imperio. Este, a la vez, «no podía permanecer indiferente ante el problema religioso, ya que la religión, según la concepción cristiana, no era uno de los tantos fenómenos sociales, sino el más importante de toda la vida, sea individual o colectiva» y el hereje o el infiel «representaban el peligro más grave, en cuanto podían corromper la sociedad y mandar a la ruina al Estadol» ${ }^{45}$.

Antes de continuar nuestra exposición y para evitar el común -y peligroso- error de no aclarar los conceptos que empleamos conviene señalar qué entendemos por herejía; según la definición del concilio de Constantinopla del 382 son herejes «aquellos que pretenden confesar la verdadera fe, pero se separan de nuestros obispos legítimos y celebran reuniones entre ellos» incidiendo en la ruptura de la unidad eclesiástica y obviando los aspectos teológicos ${ }^{46}$.

44 Gregorio de Nisa. Sobre la divinidad del Hijo y del Espfriu Santo, en: P.G. XLVI, 557 B. cit. DANIELOU, Jean-Marrou, HENRI I. Nueva historia de la Iglesia. Desde los origenes a san Gregorio magno. Madrid. Cristiandad. 1964. t. I, p. 304/5.

45 «Una peste que contagia a todo el cuerpo» según el papa Gelasio (P. L. 59, epist. XV o Codex Can. Eccl. P.L. LVI, 64). Ello ayuda a entender por qué «la Igualdad jurídica entre ortodoxo y hereje es un concepto que no entra en la mentalidad del legislador cristiano como no entraba en la mentalidad de los juristas y emperadores clásicos la igualdad entre libres y esclavos» (BIONDI, B, ll diritto romano cristiano. Milano, 1.952, t. I, P. 255).

46 Para aclarar la cuestión la propia legislación imperial determinó -en el 395- quiénes y por qué merecian tal denominación: Haereticonum vacabulo continentur... qui vel levi argumento iudicio 
«La significación otorgada al fenómeno se percibe a partir de la asociación de herejía con superstitio y de su tratamiento legislativo. Por primera se reunían en la herejía los valores ganados por superstitio en su largo devenir en tanto que símbolo peyorativo de la alteridad religiosa, predicando de conductas humanas, individuales o colectivas, Comprendía, esencialmente, los de falsa religio y magia -ésta sometida a un duro ordenamiento legal- que habían servido para la descalificación y condena de las creencias y usos ajenos a la religion oficial imperante. Así, cristianismo y maniqueísmo habían sido reprobados como supersticiones por el Estado romano y en el siglo IV, los emperadores cristianos, inclinados a hacer prevalecer el credo propio, identificarán con superstición, además de la herejía, la religio gentilicia y el judaísmo ${ }^{47}$.

Las medidas que adoptó Teodosio contra las herejías tuvieron un antecedente importante - como hemos analizado en otra oportunidad - en un edicto promulgado en la pars occidentalis por su colega Graciano, seis meses antes. Este, hasta el 379 había seguido la política de «tolerancia religiosa» implementada por su padre Valentiniano I y que contaba con la guía de su consejero, el rhetor Ausonio (Decimus Magnus Ausonius) ${ }^{48}$. Este edicto, probablemente del 3 de agosto del 379, promulgado en Milán a nombre de Graciano, Valentiniano y Teodosio, terminaba con la mentada «tolerancia religiosa» al decretar la extinción de todas las herejías vedadas «por ley divina e imperial» y prohi-

\footnotetext{
catholicae religionis et tramite detecti fuerint deviare. (Cod. Theod. XVI, 5, 28). A su vez, como veremos, el basileus Teodosio se encargó de precisar la verdadera fe en el edicto de Tesalónica, al relacionarla con la transmitida por el apóstol Pedro y profesada por el pontifice Dánaso y el obispo Pedro de Alejandría... es decir, la fijada en el concilio de Nicea. S6́lo sus seguidores eran dignos del nomen Christianonum catholiconum; los demás serán tenidos por haereticin (Cfr. Escribano, Maria Victoria. Herejia y poder en el siglo IV, en: CANDAU. J.M. y otros. La conversión de Roma. Cristianismo y paganismo. Madrid, Clásicas, 1990, p. 152/3).

${ }^{47}$ Cfr. Escribano cit. p. 41/60 y P. 153/4. Para el término superstitio en épocas previas véase Caldevone, Salvatore, en: A.N.D.R.W. Martroye observa que en las leyes teodosianas el término superstitio se aplica a las creencias judias y heréticas (Martroye, P. op. cit., p. 673). Cabe sefialar asimismo que «en tomo a esta época Epifanio, obispo de Salainina, en Chipre, había demostrado la existencia de ochenta herejfas, y en su escrito Panarion, que significa tanto como un libro de farmacopea para todos los que habían sido mordidos por la mala serpiente de los héréticos, había intentado presentar un contraveneno» (VOGT, Joseph. La decadencia de Roma. Madrid, Guadarrama, 1968, p. 203). Bloch en cambio seffala que «bajo la denominación superstitio, como en la leyes de Constantino, se entiende cualquier culto fuera de ka religión cristiana, sobre todo el pagano. Superstitio es entendida en su sentido clásico (Cicerón. De nat. deor. 11, 28, 71), esto es la antítesis de religio» (Bloch, H. Op. Cit., P. 279).

${ }^{48}$ Nacido en Bordeaux o Burdeos (Burdigala), donde enseñó apaciblemente gramática y retórica durante treinta años hasta que Valentiniano il le convocó a la corte de Tréveris (Augusta Treverorum) como preceptor de su hijo Graciano.
}

Hispania, del Mediterráneo al Atlántico

Hispania Sacra 51 (1999) 
bía a los herejes enseñar y realizar asambleas, o sea les privaba de todos los derechos civiles y religiosos (Cod. Theod. XVI, 5, 5) ${ }^{49}$.

La nueva decisión obedeció al giro de la política religiosa implementado por Graciano cuando cumplió veinte años y suele vincularse con la «caída en desgracia» del rethor Ausonio y su reemplazo como consejeros imperiales por los obispos Dámaso de Roma y Ambrosio de Milán ${ }^{50}$.

La primera disposición de Teodosio en esta materia fue el edicto, llamado de Tesalónica y conocido como Cunctos populos (por sus palabras iniciales); está fechado el 27 de febrero del 380 y prescribe textualmente: $\gg$ Deseamos que todos los pueblos (cunctos populos) regidos por nuestra imperial clemencia profesen la fe que creemos ha sido trasmitida por el divino apóstol Pedro, mantenida en su forma tradicional hasta el presente día, fe que profesan igualmente el pontífice Dámaso y el obispo Pedro de Alejandría, varón de apostóli-

49 «Los emperadores Graciano, Valentiniano y Teodosio Augustos a Hesperio, Prefecto del prretorio. Todas las herejías prohibidas por las leyes divinas o las imperiales se aquieten para siempre. Cualquier cristiano que empequeñezca la idea de Dios, con censurable audacia sienta que solamente a él ha de dañarlo esto. No expanda lo que ha de perjudicar a otros. Quien corrompe con muerte renovada los cuerpos redimidos con el dogma venerable, quitando aquellos que duplica, conozca sólo para si tales cosas, no pierda a otros con su impia conducta. Y codos los maestros y ministros de esa superstición, ellos o bien difaman con su asunción sacerdotal el nombre de sus obispos, o bien, lo que es muy semejante, con el vocablo de presbiferos mienten una religión; o bien se denominan también diáconos, Cuando ni siquiera son tenidos como cristianos. Manténganse éstos por un tiempo separados de las asambleas de esta ya hace tiempo condenada doctrina. Por fin, rechazada la respuesta que hace poco surgí en Sirmium, permanezca sobre la observancia católica sólo aquello que nuestro padre de eterna recordación y nosotros mismos hemos mandado, lo cual siempre verá vigente. Dado en Milán III non. augustus, acc. XIII kalendas septembrem [3 de agosto] bajo el consulado de Ausonio y de Olibrion [XVI, 5, 5 del 379. Las leyes del libro XVI del código teodosiano fueron traducidas por los Prof. Alfredo Schroeder y Raill Lavalle del instituto de Estudios Greco-latinos Francisco Novoa de la Pontificia universidad Católica Argentina "Santa Marla de los Buenos Aires", cuya colaboración agradecemos .

50 Graciano parece haber estado en Milán para la Pascua (12 de abril) del 379, encontrándose con el obispo Ambrosio. Palanque afirma que es consecuencia de ese encuentro un breve edicto promulgado el 22 de abril (Cod. Theod. XVI, 5, 4), que renueva la interdicción anterior de la herejía y agrega a las sanciones la confiscación de los lugares de culto (Palanque, J.R. op. cit., p. 71). Segin Paredi son fruto de este encuentro las dos leyes del 24 de abril del 380 (Cod. Theod XV, 7, 4 y 5) completadas con otras dos del 8 de mayo del 381 (Cod. Theod. XV, 7 y 8) referidas a los actores y actrices cristianos. (Paredi, A. op.cit., p. 263/4). Sordi, en cambio, sostiene que la política eclesiástica de Teodosio no es explicable por la influencia de Ambrosio, como también considera que para Graciano estudios recientes tienden a reducir o al menos a retardar el inicio del predominio de Ambrosio. (Sordi, $\mathbf{M}$. op.cit., t. 1, p. 219, nota 38). Finalmente Piganiol estima que para la abolición del edicto de tolerancia, pese a que «se piensa en san Ambrosio, a quien Graciano pudo haber visto en Sirmium en 378 y quien le demandara un manual sobre la fe; sus relaciones eran entonces más bien tibias. Y ahora sabemos que la ley de Graciano contra las heréticos es anterior en seis meses a la primera ley de Teodosio sobre la materia. Es por ello que nos inclinamos a suponer sobre todo una intervención de Dámaso, de quien sabemos que en el curso del 378 demandó y obtuvo que el brazo secular estuviera al servicio de la Iglesias (Piganiol, A. op. cit., p. 325). 
ca santidad, esto es, que según la enseñanza evangélica y disciplina apostólica, debemos creer en una deidad, la Santa Trinidad del Padre, del Hijo y el Espíritu Santo, adorados en su igual majestad. Y requerimos que los que observen esta regla de fe, abracen el título de cristianos católicos (christiani catholici), pues juzgamos a todos los demás de mente insana (dementes vesanosque) y ordenamos que sean llamados heréticos (haeretici), sus lugares de reunión no tienen derecho al nombre de iglesias; condenados como tales, en primer lugar, a sufrir el castigo divino y, con él, la venganza del poder que por celestial autoridad hemos asumido" (Cod. Teod. XVI, 1, 2) ${ }^{51}$.

Teodosio pretendía que, mediante este edicto, quedaran zanjadas por una ley imperial todas las diferencias religiosas («ideológicas») para todos los pueblos sin distinción, heréticos y paganos ${ }^{52}$. A su vez «la ley impone la fe católica, en cuanto establece sanciones en caso de inobservancia: no solo reclama el castigo divino (divina primura vindicta), sino dispone la sanción terrena, la cual se encuentra reiterada en el Código Theodosiano (XVI, 2, 25), norma emitida, siempre en Tesalónica, el mismo 27 de febrero del $380^{53}$ y que por ello se puede considerar parte de la anterior» ${ }^{54}$.

5i Schwartz (Ueber die Bischofalisten) explica la inclusión del patriarca de Alejandría porque existían dudás sobre la legitimidad de su portador, circunstancia que no se daba con Melecio de Antioquia. Otros señalan la conexión directa entre Dámaso y Pedro, que se habían reunido durante la larga estadía, del 371 al 378, del segundo en Roma y no dudan de la camarilla espafiolan (Piganiol, A. op.cit., p. 217, nota 114). Teja (p. 44/5) sefiala que «mucho se ha discutido sobre los móviles de esta medida y sus inspiradores. La mayoría de los autores modernos han querido ver detrás de ella la mano del activo papa Dámaso, que habría hecho valer su influencia también en su elección por Graciano para el trono imperial, y se ha intentado relacionar todo ello con el origen hispano de ambos. En cualquier caso, es evidente que Teodosio era un cristiano niceno convencido que ya había sido el primer emperador que al acceder se había negado a tomar el título tradicional pagano de pontifex maximus y que por las mismas fechas de promulgación del edicto se había hecho bautizar a raíz de una grave enfermedad». Stein sugiere que la medida fue consecuencia de una exigencia de Graciano para aportarle ayuda en su lucha contra los bárbaros. Cfr. STEIN, E. op. cit., t. I, p. 185) .

52 PALANQUE, J.R. op.cit., p. 116. El edicto - según Gitifredi (ad. h.l.) parece haber sido promulgado por Teodosio en Oriente $\rightarrow$ por su iniciativa personal- pero no caben dudas que la ley era universal; Biondi, en cambio, sostiene que la ley fue concertada con Graciano como complemento de su anterior del 379 (Teodoreto V, 2 la considera de Graciano) y publicada en Oriente por razones de oportunidad. (Cfr. Biondi, B. op.cit., t. I, p. 304). Por ella «el Estado se convertía en confesional, en cuanto, inspirándose en el caracter universal y la unidad de la iglesia, decidfa que todos los ciudadanos abracen la fe católica: cunctos populos $\$ 66$ lo aquellos que profesan la fe, precisada en la misma ley, se pueden llamar con el nombre de cristianos, mientras que los otros son considerados dementes vesanosques [Cfr. BIONDI, B. op. cit., t. L, p. 305).

53 «Los emperadores Graciano, Valentiniano y Teodosio Augustos. Quienes confunden por ignorancia la santidad de la ley divina, o bien la violan y ofenden por negligencia, cometen sacrilegio. Dado en Tesalónica a III kalendas martius [el 27 de febrero], bajo el consulado de Graciano Augusto, por quinta vez, y de Teodosio Augusto, por primera vezs [XVL, 2, 25 del 380].

54 Cfr. BloNDI, B. op. cit., t. 1, p. 306.

Hispania, del Mediterráneo al Atlántico

Hispania Sacra 51 (1999) 
De la sola lectura del texto surge con claridad que el documento no se dirige a los paganos sino, fundamentalmente, a los herejes, y entre ellos presumiblemente a los renacientes - y siempre peligrosos-arrianos ${ }^{55}$.

El arrianismo, que había contado con el favor imperial de Valente, comenzó a desaparecer rápidamente salvo en el Illyricum y en Milán, donde le dio aire la propia emperatriz Justina ${ }^{56}$ cuando llegó exilada desde Sirmio en el lírico, en otoño del 378, con su hijo y con otros prófugos danubianos.

«El edicto de Tesalónica tenía fuerza de ley y manifestaba la extrema decisión de Teodosio de poner fin, antes que nada por razones políticas, a la eterna división oriental entre arrianos y antiarrianos» ${ }^{57}$.

Decidido a no quedarse en el plano de las intenciones Teodosio dispuso aplicarlo inmediatamente y el 27 de noviembre del 380, tres días después de su llegada a Constantinopla, presiono al anciano obispo Demófilos -que era arriano- para que aceptase el credo niceno. Al negarse, fue depuesto y a los pocos días, en su reemplazo, tomaba posesión de la iglesia de los Santos Apóstoles un discípulo del teólogo capadocio Basilios de Cesarea: Gregorio de Nacianzo (Grigorios de Nazianzus) ${ }^{58}$. Las tropas imperiales dispersaron a los tumultuosos, se desterr6 a obispos arrianos y las iglesias que ocupaban fueron entregadas a los católicos. Nuevos disturbios llevaron a Gregorio a renunciar a su sede ${ }^{59}$ y al año siguiente el propio basileus, ante los graves disturbios, impuso al jurista y senador laico Nectarios, que fue ordenado al efecto ${ }^{60}$.

El 10 de enero del 381 Teodosio reiteró las disposiciones del edicto de Tesalónica por medio de un nuevo edicto (Cod. Theod. XVI, 5, 6) donde confir-

55 Cabe recordar que el arrianismo fue predicado por el monje Ario nacido en Baucalis, en la Cirenaica, la actual Libia, quien habia estudiado en la «escuela teológico de Antioquia» -más racionalista que la de Alejandría, de orientación alegorica- y afimaba que existía un único Dios eterno e increado y que el verbo era una criatura del Padre, o sea que no era de naturaleza divina. Sus ideas fueron condenadas formalmente en el concilio de Nicea, en el 325, donde se resolvi6 que el Hijo era consustancial con el Padre (homoousios) y no de naturaleza semejante (homoiousios).

56 Viuda de Magnecio, célebre por su belleza, casó en segundas nupcias con Valentiniano I en el 369/70. Paredi destaca que aunque se trató de un escándalo (S/Socrates IV, 31) ninguna autoridad eclesiástica excomulgó al emperador (PAREDI, Angelo. San Ambrogio e la sua etá. Milano, U. Hoepli, 1994, 435). Con Justina tuvo cuatro hijos: Valentiniano II, Justa, Grata y Gala

57 PAREDI, A. op. cit. p. 262.

58 Sozomeno VI, 5, 7. Este, canónicamente, ya era obispo electo de Sasima, en Asia y por ello se le opuso parte del clero liderado por su colega Melecio (Meletios) de Antioquía.

59 Según relata el propio Gregorio se produjeron alborotos «como si yo en lugar de un Dios quisiera introducir varios dioses» (Cfr. Camen de vita sua. $652 \mathrm{~s}, 665$ s, 1305 s, epist. LXXVII, Oratio XIX, 14; XXV; XXXIII, 5 ; XXXV, 3 y XLII.

60 Este fue «confirmado por el concilio ecuménico de Constantinopla, en presencia del emperador Teodosio y todo el clero y por común elección de la ciudad toda» (Sozomeno VII, 9 y Teodoreto $\mathrm{V}, 9,15)$. 
maba la fe de Nicea y vedaba el culto a quienes no profesasen esa fe, prohibía sus reuniones y establecía penas concretas para los incumplidores. El interés del edicto radica en que fija por decreto imperial como única fe verdadera la establecida por el concilio de Nicea de «la cual no es lícito desviarse en ningún punto ni de menor importancia (vel levi argumento) $\rangle^{61}$.

Cabe señalar que a diferencia del edicto de Tesalónica ahora se precisa la verdadera fe, no en la creencia de los obispos de Roma y Alejandría sino en el concilio de Nicea; agregándose para reforzar la argumentación la parte más controvertida del credo niceno: «Cristo deum de deo, lumen de lumine, la sustancia indivisa de la Trinidad y se enuncia una rápida definición de la sustancia (substancia, quae Graeci adsertione verbi ousia dicitur)» ${ }^{62}$.

Por otro edicto, del 8 de mayo ${ }^{63}$ se castigó a los maniqueos; comprendiendo bajo este nombre a una serie de sectas que expresamente menciona el edicto: los encratitas ${ }^{64}$, saccophoros ${ }^{65}$, apotácticos ${ }^{66}$, hydropastastes ${ }^{67}$.

61 «Los Emperadores Graciano, Valentiniano y Teodosio Augusto a Eutropio, Prefecto del Pretorio. No deberá haber lugar ni ocasión para los herejes de celebrar sus misterios, de manifestar la insensatez de su ánimo tan obstinado. Sepan todos también que si estos hombres han obtenido algo por cualquier rescripto conseguido por fraude, no tendrá validez. Las turbas de los herejes deben ser separadas de sus ilicitas congregaciones. El nombre del sumo y único Dios debe ser celebrado en todas parte; Siempre deberá permanecer la observancia de la fe nicena, desde tiempo atrás entregada por nuestros mayores y confirmada por el testimonio y la afirmación de la religión divina; la contaminación de la mancha fotiniana, el veneno del sacrilegio arriano, el crimen de la perfidia eunomiana y los horrores de las sectas, que tienen a nombres monstruosos como autores, sean todas ellas suprimidas desde el preciso momento en que se tenga noticia. Pero deberá ser considerado afirmante de la fe nicena y cultor de la verdadera religión católica todo aquel que confiese al Díos omnipotente y a Cristo Hijo de Dios con un solo nombre, Dios de Dios, luz de luz, aquel que no deshonre negándolo al Espiritu Santo, a quien espéramos y recibimos del sumo Padre de todas las cosas: aquel en quien, en el conocimiento de la fe inviolable permanece la indivisa substancia de la Incorrupta Trinidad, que correctamente es llamada por los creyentes, valiéndose del término griego, usía. Estas cosas son las que nosotros ciertamente más aprobamos, las que deberán ser veneradas. Pero todos los que no sirven a esta doctrina dejen de adjudicarse, con estudiados engaños, el nombre de verdadera religion, que les es ajenos sean conocidos por sus manifiestos delitos. Que sean alejados por completo del umbral de toda las iglesias: nosotros prohibimos, en efecto, que todos estos herejes realicen dentro de las cilldades sus ilícitas congregaciones; y, si esta facciosa erupción intentará algo, mandanos que para exterminar su furor sean expulsados de las propias murallas de las ciudades, para que todas las Iglesias católicas en todo el mundo sean devueltas a todos tos obispos ortodoxos, que tienen la fe nicena. Dada el 10 de enero en Constantinopla, bajo el consulado de Euquerio y Siagrion.

62 PIGANIOL, A. op, citt., p. 218. Para el credo de Nicea cfr. DENZINGER, Enrique. El magisterio de la Iglesia. Barcelona, Herder, 1963, p. 23.

63 Agregarnos a aquella sanción también ésto: que no constituyan, ni en las pequeñas agrupaciones de las ciudades ni en las ciudades ilustres, los sepulcros acostumbrados a los dioses manes. Sean totalmente eliminadas de la vista de las poblaciones populosas; y no se defienda, con malicioso engaño y falaz simulación, con aquellos nombres con que la mayoria, como sabemos, de probada fe y de propósitos más castos querrían ser llamados y nombrados. En especial, algunos de éstos querrían Ser

Hispania, del Mediterráneo al Atlántico

Hispania Sacra 51 (1999) 
Casi al mismo tiempo un sínodo de ciento cincuenta y tres obispos de la pars orientalis, presidido por Melecio de Antioquía, dio fin a las controversias teológicas y aceptó la fe nicea, el Nicaenum, suscribiendo el tomus latino redactado por el concilio de Roma, que Dámaso había presidido en 372 y mandó las actas a Roma sub Damaso papa ${ }^{68}$.

Pero el edicto no fue suficiente para solucionar todos las diferencias existentes -aún en Antioquía- y por eso en el 380, el emperador, para unificar las creencias en la línea establecida de Cunctos populos, presionó por la realización de un concilio en Constantinopla, que clarificara el tema. Al concluir éste, el 9 de julio, los padres conciliares elevaron una carta al emperador informando sus tareas y agradeciendo a Dios por haberlo elegido para procurar la paz de las iglesias y defender la verdadera fe; asimismo le recordaban su misión de mantener la concordia, confesar la fe de Nicea y anatemizar los errores contrarios a dicha fe, mediante la confirmación de las decisiones conciliares» ${ }^{69}$.

Como respuesta Teodosio promulgó el 30 de julio del 381 un nuevo edicto (Cod.Theod. XVI, 1, 3) ${ }^{70}$ confirmatorio de las decisiones del concilio, en el

denominados encratitas, apotactitas, hidroparastatas o sacroforos, y con variedad de nombres diversos, como mintiendo en los deberes de su profesión religiosa. Pues conviene que todos ellos no sean defendidos por la profesión de sus nombres, sino que sean reprobables y execrables por la maldad de sus sectas. Dado en Constantinopla a VII ldus maius [8 de mayo], bajo el consulado de Eúquerio y de Siagrio" (XVI, 5, 7, 3).

64 Según Epitanio <Haereseses. XIVII, 1, 1/3> condenan el matrimonio el uso del vino y de la carne animal; se difundieron en Asia Menor y especialmente en la Pisidia y en Frigia, pero también en Isauria, Panfilia, Cilicia y la Galacia. Cfr. para éste y siguientes De Giovanni, L. op. cit., p. 93/7. Según Blazquez esta herejía había sido fundada por el apologista Taciano, discípulo de Justino y se caracterizo por rechazar el matrimonio como adulterio, por condenar la comida de carnes y por sustituir el vino por el agua en la Eucaristía (en: «El cristianismo religión oficial», en: Historia 16, XXI, 249, enero 1997 , p. 64)

65 Sabemos poco de ellos pero es probable que se trate de un confuso grupo ascético mezclado con los maniqueos, cuyo nombre provendría del uso de telas de saco o costal

66 Rama de los encratistas que se comprometían a imitar la pureza de los Apóstoles y levar una vida ascética. Poco numerosos se encontraban sobre todo en Frigia, Cilicia y Panfilia (Epiphanio. Haer. LXI., 2, 1)

$67 \mathrm{O}$ acuarios, así llamados porque, como los maniqueos con quienes se confundía, consideraban ilícito usar en la consagración eucarística solamente agua y no vino. El obispo cartaginés Cipriano los acusa de ignorantes (Epist. LXIII, 14).

68 Cfr. PALANQUB-BARDY-LABRIOLle. Histoire de l'Eglise. De la paix consfantilnienne a la mort de Theodose: en Hist. Fliche-Martin, t. III, p. 283, nota 6. Finalnente, sin duda, recae sobre este concilio el mérito de haber reunido el primer corpus de cánones de la Iglesia» (PIGANIOL, A. op. cit., p. 216).

69 Cfr. Mansi. 111, col. 557. PalanQue-Dardy-Labriolle. op. cit., p. 291.

70 «Los mismos Augustos [Graciano, Valentiniano y Teodosio] a Auxonio, procónsul de Asia. Mandamos que todas las Iglesias sean entregadas a los obispos que confiesen al Padre, al Hijo y al Espíritu Santo de una majestad y poder, de una misma gloria y único resplandor. Tales obispos no bacen, con profunda division, nada disonante, sino que manifiestan el orden de la Trinidad en la 
que reiteraba la devolución de las iglesias a los niceno ${ }^{71}$, dispuesta por el edicto del 10 de enero del 381 y mal cumplido. A su vez los eunomiamos, Ios arrianos y los adherentes al dogma de Aecio $^{72}$ o tenían el derecho de levantar iglesias, bajo pena de confiscación del edificio eventualmente construido (Cod. Theod. XVI, 5, 8) ${ }^{73}$

Así ahora, «después del edicto de Tesalónica del 380, que reconocía la confesión nicena, los otros grupos religiosos no tenían garantía legal alguna y todo culto herético estaba formalmente proscripto en el interior de las ciudades (leyes del 10 de enero del 381 y del 10 de marzo y 14 de junio del 388) ${ }^{74}$.

En marzo del 382 se agravaron las penas contra los maniqueos, que fueron calificados de solitarii (Cod. Theod. XVI, 5, 9) ${ }^{75}$ Los encratistas fueron penados de muerte. El 10 de junio del 383 condenó a los tascodrogitae ${ }^{76}$.

confesión de las personas y en la unidad de la divinidad. Nos consta que están en comunión con Nectario, obispo de la Iglesia de Constantinopla, y de Timoteo, obispo en Egipto de la ciudad de Alejandría; en las partes de oriente, con Pelagio, obispo de Laodicea, y con Diodoro, obispo de Tarso; en Asia y en la diócesis asiática y proconsular con Anfiloquio, obispo de Iconio, y con Óptimo, obispo de Antioquía; en la diócesis del Ponto, con Heladio, obispo de Cesarea y con Otreyo Meliteno y con Gregorio niseno, con Terencio, obispo de Escitia, y con Marmario, obispo de Marcianópolis. Será necesario admitirlos a éstos para conseguir iglesias católicas a partir de la conunión y la comanidad de sus sacerdotes más acreditados. Pero será necesario que todos los que disienten de la conunión de la fe de aquélos, que han sido especialmente recomendados, sean expulsados de las iglesias como manifiestos herejes, y que no les sea permitido en absoluto después el pontificado y la posibilidad de obtener iglesias a fin de que permanezcan verdaderos y castos los sacerdotes de la fe nicea y que no se les dé lugar a una maligna astucia, después de la clara formulación de este nuestro mandato. Dado el III kalendas de augustus [ 30 de jutio] en Heraclea, bajo el consulado de Buquerio y Siagrios.

7 Cfr. con el edicto de Milán.

72 Heresiarca del siglo IV que condujo a las consecuencias extremas las tesis de Arrio sostenien* do que el Hijo no era similar al Padre sino que era de otra sustancia. Cfr. Epiphanio. Haer. LXXVI, 2.

73 «Los mismos Augurtos [Graciano, Valentiniano y Teodosio] a Cliquerio, conde de Oriente. Ordenamos que ninguno de los eunonianos y arrianos, o los partidarios del dogma de Aecio, tenga la facultad de fundar iglesias en la ciudad y en los campos. $Y$ si esto fuere temerariamente asumido por alguien, la casa misma, donde hubiere sido construido esta que se prohibe, también la propiedad o la posesión privada de inmediato sean adjudicadas a los recursos de nuestro fisco; y todos los lugares que ya los hayan recibido como sede de este sacrilego dogma, o como ministros, indiatamente se convierten en fiscales. Dado en Constantinopla XIIII kalendas augustus [19 de julio], bajo el consulado de Euquerio y Siagrio- [XVI, 5, 8 del 381.

${ }^{74}$ PALANQUE, J.R. op. cit, p. 205, nota 37.

75 «Los mismos Augustos [Graciano, Valentiniano y Teodosioj a Floro, prefecto del Pretorio. Cualquier maniqueo que rehuya la unión con los buenos, con el falso pretexto de una vida solitaria, y elija las turbas secretas de los peores, como profanador y corruptor de la disciplina católica, que todos veneramos, sea sometido a la ley. Que viva sin testar, que en vida no se dedique a cosas ilfcitas, que al morir no deje nada a hombres indignos, que restituya todo al projimo - no según sus costumbres, sino projimo según la naturaleza. Si le faltare legítima sucesión, que abandone sus cosas, dignas de mejor uso. Ellas pertenecerán al fisco sin ningún tipo de fraude, puesto que hay defecto de agnacion. Esto es lo que mandamos acerca de los solitarios».

Hispania, del Mediterráneo al Atlántico

Hispania Sacra 51 (1999) 
Como parte de su permanente intento de terminar con todas las controversias pendientes, Teodosio convocó en el 383, en Constantinopla, una reunión de los dirigentes de las diversas confesiones ${ }^{77}$. El coloquio no llegó a ningún resultado y el basileus cortó los debates, prohibiendo todas las declaraciones heterodoxas.

El basileus promulgó otras tres constituciones respectivamente el 25 de julio (Cod. Theod. XVI, 5, 11) ${ }^{78}$, el 3 de septiembre del 383 (Cod. Theod. XVI, $5,12)^{79}$ y el 21 de enero del 384 (Cod. Theod. XVI, 5, 13) ${ }^{80}$, las que prohibían

76 Secta de origen montanista fundada por el frigio Montano que sostenía el pronto regreso del Paráclito y que se meten los dedos en la nariz (sic) (Cod. Theod. XVI, 5, 10) y Epiphanio. Haer. XIVIII, 14, 4). Cabe observar que se ha constatado que kel Código teodosiano -promulgado en el 438 - ha conservado sesenta y siete constituciones entre los años 381 y 438, persiguiendo a las herejías, a las que habrfa que añadir sin duda muchos textos perdidos» (CELADA, Gregorio. «Experiencia de la comunión en la Iglesia antigua», en: Ciencia Tomista. 353, octubre 1980, p. 531).

7 Sócrates v, 10, Sozomeno VII, 12: Gregorio de Hacianzo. Epist. CLXXV.

78 «Los mismos Augustos [Graciano, Valentiniano y Teodosio] a Postuniano, prefecto del Pretorio. Absolutamente todos aquellos a quienes mueve el error de diversas herejías (los eunomianos, los arrianos, los macedonianos, los pneumatónacos maniqueos, los encratitas, Ios apotactitas, los sacóforos y los hidroparastas) en ninguna clase de círculos se reúnan, no convoquen ninguna multitud, no atraigan ningún poblado ni hagan de sus propias paredes iglesias, no practiquen ni en público ni en privado nada que pueda dar̃ar la santidad de la Iglesia Católica. Pero si apareciera alguien que transgreda lo que tan claramente prohibimos, damos potestad a todos aquellos que se complacen en la belleza y en el culto de la recta observancia, para que éste quede sin participar en los bienes comunes. Dado en Constantinopla, a VIII kalenda augustus un [25 de julio], bajo el consulado de Merobaudo, por segunda vez, y de Saturninos (XVL, 5, 11).

${ }_{79}$ Los mismos Augustos [Graciano, Valentiniano y Teodosio] a Postumiano. Esa cuna de vicios, odiosa a Dios y a los hombres -nos referimos a las herejías eunomiana, arriana, macedonia, apolinaria y a las demás sectas, las cuales, con el culto de la verdadera religion, condena la fe sincera- no tendrán facultad de formar iglesias ni congregaciones, ni en lugares públicos ni en ámbitos privados, dentro de las ciudades o en las villas y en los campos. Tampoco pretendan celebrar su perfidia o participar en sus insensatas reuniones, ni realizar ningún tipo de ordenaciones sacerdotales. Las casas en las ciudades o en cualquier otro lugar, en que sus profesantes o ministros celebren la pascua, queden bajo el dominio y derecho de nuestro fisco. De este modo, quienes tienen por costumbre participar en tales enseñanzas, ritos o reuniones, sean buscados y echados de todas las ciudades y lugares, obligados por la fuerza de esta ley; mandamos también que vuelvan a las tierras de donde vinieron, y que ninguno de ellos tenga potestad de ir a otras ciudades o de vagar por cualquier lugar. Si estos mandatos de Nuestra Serenidad son cumplidos con negligencia, el personal de los jueces de las provincias, y los principales de las ciudades, donde se descubra cualquiera de estas ilícitas reuniones, padezcan nuestra sentencia y condenación. Dado en Constantinopla, a III nonas december [3 de diciembre], bajo el consulado de Merobaudo, por segunda vez, y de satumino.

\$o «Los mismos Augustos [Graciano, Valentiniano y Teodosio] a Cinegio, prefecto del Pretorio. Los eunomianos, macedonianos, arrianos y apolinarianos, en lo tocante a los deberes de la sagrada religión, son nombres famosos por sus propios enrores. Por tanto, todos los que reivindicaron para sí ya el pontificado ya el ministerio de estas profesiones: quienes se proclaman sacerdotes de un nombre condenado; quienes en una religión que es motivo de acusación, se imponen el nombre de Ministros; quienes aseguran enseñar aquello, que sería mejor ignorar o bien olvidar, sean expulsados después 
las reuniones de los herejes (eunomianos, arrianos, macedonios o pneumatomaquicos, encratistas y apollinaristas $)^{81}$ y todo otro acto de proselitismo, asimismo se les prohibía poseer lugares de culto y podían ser echados de sus capillas.

A su vez, en Occidente, donde había resurgido el arrianismo bajo el joven Valentiniano II, influenciado por su madre Justina, Teodosio, al pisar sus territorios, dispuso desde Stobi, el 14 de junio del 388 derogar la ley «de tolerancia» del 23 de enero del 386 que, por otra parte, jamás fue seriamente aplicada y prohibir a los «herejes» reunirse y predicar, construir altares y celebrar cualquier tipo de servicio religioso (Cod. Theod. XVI, 5, 15) ${ }^{82}$

Algunos años más tarde (387) los arrianos fueron nuevamente condenados (Cod. Theod. XVI, 5, 16) ${ }^{83}$. A su vez, desde Milán, el 4 de mayo del 389, por edicto dirigido al prefecto de Oriente Tatiano dispone la incapacidad civil de los eunomianos o anomenos (Cod. Theod. XVI, 5, 17) ${ }^{84}$. Del mismo modo los

que se examinen a fondo los escondrijos de esta ciudad, con una indagación más escrupulosa sin ningún tipo de clemencia. Que vivan en otros lugares y sean separados totalmente de las reuniones de los buenos. Dado en Constantinopla, a XVI kalendas de februarius [21 de enero], bajo el consulado de Ricomer y de Clearco varones clarísimos» (XVI, 5, 13).

81 Los apolinaristas eran seguidores de Apollinar, quien sostenía que Cristo jamás habla poseído alma humana y en él estaba el Verbo divino que cumplía el papel de Ia inteligencia. PALANQUEBARDY-LABRIOLIE. op. cit., p. 296.

82 «Los mismos Augustos [Graciano, Valentiniano y Teodosio] a Trifolio, prefecto del Pretorio. todos los integrantes de las diversas y perfida sectas, a quienes incita la locura de una miserable conspiración contra Dios, no les sea permitido tener en ningún lugar acuerdo alguno, ni entrar en trato alguno ni mantener reuniones secretas. No se les debe pernitir que sus manos levanten vergonzosamente altares a los servicios de una impía prevaricación, y que adopten la sinulación de los misterios, para injuria de la verdadera religión. Para que se logre el efecto adecuado, constinuya tu Alteza, en su vigilancia, a todos los más fieles, para que puedan reprimir a éstos y, una vez aprendidos, llevarles a juicio. Así, serán sometidos a Dios y a las leyes, con castigo severísimo, segin las anteriores sanciones. Dado en Stobi [Estobos], a XVII kalendas iulius [14 de junio], bajo el consulado de Teodosio Augusto por segunda vez, y de Cinegio, varón clarísimo».

83 Los mismos Augustos [Graciano, Valentiniano y Teodosio] a Cinegio, prefecto del Pretorio. Hemos descubierto que algunos arrianos dan tal forma a nuestros mandatos, que parece les fuera lícito servirse de aquellos que les resulte útil. Quitada esta interpretación, sepan que nada de eso ha salido de nuestro santuario. Cualquier cosa de este tenor, y cualquiera que intente introducirla, serán considerados reos de falsedad. Dado en Constantinopla, a V idus augustus [ 9 de agosto], bajo el consulado de Teodosio Augusto, por segunda vez, y de Cinegio, varón clarísimon.

84 Los emperadores Valentianiano, Teodosio y Arcadio Augustos a Taciano, prefecto del Pretorio. Los eunucos eunomianos no tengan facultad ni de hacer ni de obtener testamento. En lo que concierne a todos los que la ley ha encontrado vivos, queremos que nadie se defienda con el privilegio de cualquier voluntad pasada, cuando se muestren testamentos hechos anteriormente o no hechos. Después de esta sanción de nuestro oráculo, no tengan facultad ni de pedir ni incluso de dejar un heredero con nombre principal, ni a un fideiconiso ni a un legatario ni a un tácito fideicomiso, $o$ cualquiera sea la denominación que el derecho ha previsto para estos casos: sino que todo lo que se ha establecido que es o será de tales hombres, sea reivindicado como caduco, en beneficio de nuestro 
maniqueos, ya proscriptos por Dioclesiano y sancionados por Valentiniano I el año 372 (Cod. Theod. XVI, 5, 3), a quienes se les negó el derecho a testar el 8 de mayo del 381 y el 31 de marzo del 382 (Cod. Theod. XVI, 5, 7 y 9) ${ }^{85}$, fueron interdictos en Roma por un edicto fechado el 17 de junio del 389 (Cod. Theod. XVI, 5,18$)^{86}$. Un nuevo edicto dirigido al prefecto Tatiano de oriente confirmó, el 26 de noviembre del 389, la interdicción de los arrianos (Cod. Theod. XVI, 5, 19) ${ }^{87}$, ratificando la disposición del 21 de enero del 384 (Cod. Theod. XVI, 5, 13) ${ }^{88}$.

«El legislador prohibe el debate público sobre religión; el súbdito puede manifestar su fe solo en las formas y modos oficialmente reconocidos; está prohibida toda asamblea, el culto no puede desarrollarse si no en las sacrosanctae ecclesiae. Está claro que al legislador no le interesa tanto la fe personal del súbdito ni si adhiere al menos en lo íntimo a la ortodoxia; le interesa sobre todo que manifieste formalmente y en público su adhesión a la religión

fisco. En suma, nada tengan en común con los restantes. Dado en Milán, a IIII nonas maius [4 de nayo], bajo el consulado de Tinasio y Promotor.

${ }^{85}$ Los mismos Augustos [Graciano, Valentiniano y Teodosio] a Eutropio, prefecto del Pretorio. $\mathrm{Si}$ algún maniqueo o maniquea, desde el día, ya antiguo, de la promulgaclón de esta ley por nuestros padres, ha trasmitido sus propias facultades a cualquier persona por testamento o en razón de cualquier especie de liberalidad o donacion, o si algunos de ellos fue enriquecido por cualquier forma de sucesión; puesto que inmediatamente les hemos quitado toda facultad de tentar y de vivir bajo el derecho romano, y no le permitiremos dejar ni adquirir nada por herencia, mandamos que todo sea asignado a los recursos de nuestro fisco, (XVL, 5, 7).

86 «Los mismos Augustos [Albino, Valentiniano, Teodosio y Arcadio] a Eutropio, prefecto de la ciudad. Quienesquiera que bajo el nombre de maniqueos inquietan al mundo sean expulsados, bajo amenaza de juicio, de toda la tierra, pero sobre todo de esta ciudad» $(X V I, 5,18)$ y uQue sus voluntades, incluso sus propias facultades hechas públicas al pueblo, no tengan fuerza de testamentos ni sea permitido a ellos ni a través de ellos dejar en herencia. Que nada tengan ellos en común con el mundo. Roma, XV kalendag de iullus [17 de junio], bajo el consulado de Timasio y Promoton (XVI, 5, 18, I).

87 «Los mismos Augustos [Valentiniano, Teodosio y Arcadio] a Taciano, Prefecto del Pretorio Aquellos que tienen el principado de un dogma siniestro, esto es los obispos, presbíteros, diáconos y lectores, y cualquier otro que bajo el velo del estado clerical intenta ocasionar una mancha a la religion, en nombre de cualquier herejía o error; sean ellos alejados de todo funesto conciliábulo, ya sea dentro de la ciudad o en lugares subalternos. Milán, VI Kalenda december [26 de noviembre, bajo el consulado de Tinasio y Promoto» (XVI, 5, 19, 389)

88 «Los mismos Augustos [Graciano, Valentiniano y Teodosio] a Cinegio, prefecto del Pretorio Los eunomianos, macedonianos, arrianos y apolinarianos, en lo tocante a los deberes de la sagrada religión, son nombres famosos por sus propios errores. Por tanto, todos los que reivindicaron para sí ya el pontificado ya el ministerio de estas profesiones: quienes se proclaman sacerdotes de un nombre condenado; quienes en una religion que es motivo de acusación, se imponen el nombre de ministros; quienes aseguran enseffar aquello, que sería mejor ignorar o bien olvidar, sean expulsados después que se examinen a fondo los escondrijos de esta ciudad, con una indagación más escrupulosa sin ningún tipo de clemencia. Que vivan en otros lugares y sean separados totalmente de las reuniones de los buenos. Dado en Constantinopla, a XII kalendas de februarius [21 de enero], bajo el consulado de Ricomer y de Clearco varones clarísimos» (XVI, 5, 13). 
católica en la asamblea reconocida por la ley ${ }^{89}$. Esta prohibición, de discutir temas religiosos, afectaba también a los cristianos fuera de los templos.

En el 391, después de diez años de interrupción, los herejes volvieron a inquietar la península itálica y por edicto fechado en Roma el 19 de mayo del 391 fueron prohibidas sus reuniones en las ciudades y villas (Cod.Theod. XVI, $5,20)^{90}$, como tampoco podían efectuar consagraciones episcopales $\mathbf{u}$ ordenaciones sacerdotales según decretos del 15 de junio del 392 (Cod. Theod. XVI, $5,21)^{91}$ y del 15 de abril del 394 (Cod. Theod. XVII, 5, 22) ${ }^{92}$. La privación de derechos civiles a los herejes fue renovada y extendida a todos, a la muerte de Teodosio, por su hijo y sucesor Arcadio el 24 de noviembre del 395 (Cod. Theod. XVI, 2, 29) ${ }^{93}$.

Una vez desterrada legalmente la herejía, en cuanto a la actitud imperial frente a los herejes, el historiador Sozomeno, aclara que aunque «amenazó con graves penas a los herejes, no los persiguió porque su fin no era penar efecti-

89 De GIovanNI, L. $I$ libro XVI del codice teodosiano. Napoli. M. D'Auria, 1985. p. 75/6.

90 Mandamos, según ejemplo de las Sagradas Escrituras, que el sucio contagio de los herejes sea echado de la ciudad, expulsado de las aldeas, y que no se junten en ninguna clase de reunión, a fin de evitar que esa sacrílega cohorte de hombres se junte en lugar alguno. Que no se otorgue a su perversidad y a sus errores ningún lugar público ni oculto. Roma, XIII kalendas iunius [19 de mayo], bajo el quinto consulado de Taciano y Símaco» [XVI, 5, 20; 391]

91 Los mismos Auqustos [Valentiniano, Teodoslo y Arcadio] a Taciano, Prefecto del Pretorio. Decretamos que los errados herejes que conste hayan ordenado clérigos o recibido el oficio de clérigos sean multados, individualmente, en diez libras de oro. Decretamos también que el lugar en que intenten llevar a cabo actos prohibidos, si esto ocurriera con consentimiento disimulado del dueño, sea agregado a los recursos de nuestro fisco. Pero si constara que su posesor lo ignora, por haberse hecho estos actos en secreto, mandamos que su arrendatario, si es de condición libre, aporte diez libras a nuestro fisco: si desciende de la hez servil y desprecia, por su vileza y pobreza, el castigo, será golpeado a palos y deportado. Además mandamos especialmente que, si la villa propiedad de su señor o de cualquier derecho público fuera alquilada, y su mandatario y arrendatario les dieran permiso de reunirse, sean ellos condenados y multados en diez libras de oro. Y si se descubre que algunos favorecen tales ritos y se apropian indebidamente del nombre de clérigos, mandamos que cada uno de ellos aporte diez libras de oro. Constantinopla 17 kalendas iulius [15 de junio], bajo el consulado de Arcadio Augusto y, por segunda vez, de Rufinos (XVI, 5, 21).

92 «Los Emperadores Teodosio, Arcadio y Honorio Augustos a Vicario, Procónsul de Asia. Que los heréticos no tengan potestad de hacer obispos ni sean ilícitas sus confirmaciones episcopales. Constantinopla XVII Kalendas maius [15 de abril], bajo el consulado de Arcadio por tercera vez y de Honorio por sequndas (XVI, 5, 22).

93 Los emperadores Arcadio y Honorio Augustos a Hierio, vicario de Africa. Todo lo que ha sido establecido en diversas épocas por nuestros antepasados, ordenamos que permanezca inviolable e incorrupto, en lo que a las sacrosantas iglesias se refiere. Por tanto, nada sea modificado de sus privilegios, y a todos los que están al servicio de las iglesias les sea dada una protección, porque en nuestros tiempos deseamos que se añada más reverencia, más bien que se modifique algo de lo que había sido concedido en otro tiempo. Dado en Milán a X kalendas aprilis [23 de marzo], bajo el consulado de Olibrio y de Probino» (XVI, 2, 29).

Hispania, del Mediterráneo al Atlántico

Hispania Sacra 51 (1999) 
vamente a los súbditos sino empujarlos para que aceptasen sus mismas ideas en torno a la divinidad ${ }^{94}$.

Este aspecto es recalcado por De Giovanni cuando observa que la legislación no miraba a la eliminación física del hereje. Por el contrario «el legislador tiende a marginar al hereje, a alejarlo al menos hasta que retorne a la ortodoxia. Las constituciones muchas veces afirman que el hereje no pertenece a la comunidad humana y que así, no lo resguardan las leyes que reglan la convivencia de los hombres ${ }^{95}$. Por ello «resulta necesario levantar un «muro» entre los herejes y el resto del género humano; este propósito del legislador explica porqué el herético es condenado al exilio en las afueras de los muros de la ciudad o, si propaga su fe en lugares diversos al de origen, sea devuelto a su país nativo» ${ }^{96}$.

«La defensa de la fe católica es para el legislador un deber de primera importancia, porque identifica los intereses de la colectividad con los de la sacrosancta ecclesia catholica. El hereje es, por ello, aquel que atenta no solo contra la integridad de una fe religiosa, que cuenta con apoyo del Estado, sino además, y por los mismos motivos, contra los intereses de toda la sociedad. De esta premisa, la conclusión sobre el plano jurídico es obvia: la herejía es, por definición, un crimen publicum, como expresa explícitamente todavía una ley de Honorio (Cod. Theod. XVI, 5, 40). El ordenamiento jurídico debe por tanto proveer a que la herejía, convertida en «pestilencia» y «contagio» (Cod. Theod. XVI, 5, 44 del 408), no se difunda en modo alguno» ${ }^{97}$. Por ello «la legislación referida a los herejes es, también, promulgada pro religione catholicae sanctitatis. Es necesario entender bien que el Estado no se arroga la competencia de discernir, en las disputas religiosas, la tesis ortodoxas de las heréticas. El Estado interviene contra éste a aquel movimiento herético solo por pedido directo de los obispos católicos o de los concilios, o también cuando, por razones generales de carácter político o religioso, decide autónoma-m mente promulgar disposiciones contra grupos condenados por la jerarquía eclesiástica. Las penas amenazantes son muchas; el objetivo del legislador no es la pena en sí del hereje sino, en última instancia, su conversión. La pena debe ser aplicada únicamente como extrema ratio, en el caso que el reo no haya dado ninguna señal de querer regresar a la ortodoxia» ${ }^{98}$.

\footnotetext{
94 Sozomeno VII; 7 12, 12. DE GlovanNI, L. op. cit., p. 81.

95 De GiovanNi, L. op. cit., p. 81.

96 Cfr. Cod. Theod. XVI, 5, 6; XII, XIV, 20; XXXI; XXXIV y LXIV. DE GIovaNNI, L. op.

97 DE GrovanNI, L. op. cit.. p. 77/S.

98 Idem, p. 78
} cit., p. 84. 


\section{LAS MEDIDAS CONTRA LAS TRADICIONES ROMANAS.}

En la historia de los dos primeros siglos del cristianismo encontramos permanentes enfrentamientos con el Imperio romano, comunmente conocidos como «las persecuciones», pero también hubo sucesivos intentos de encuentros $^{99}$; sin éstos últimos hubieran sido imposibles o al menos inoperantes los edictos de los emperadores Constantino y Teodosio.

Pero una una vez legitimada, formalmente aceptada e incorporada a los estamentos del poder la Iglesia debió soportar las luchas contra los cultores de la religión tradicional romana - ahora denominados paganos-y sus propia disenciones internas ${ }^{100}$.

La «religión» que ahora pasó a conocerse como paganismo no era más que el sincretismo confuso y asistemático de antiguas creencias (culto a los antepasados, pignora) teñidas de neoplatonismo y cultos orientales ${ }^{101}$ y costumbres vinculadas a los antepasados (mores maiorem) cuya fídes constituía, más que el culto capitalino, la base del patriotismo romano. Sus cultores mas importantes no fueron los ciudadanos masivamente incorporados, sino una intelectualidad romana de sofistas y rethores como Libanios, Themistios, Ausonio o Claudiano, que identificaban el paganismo con la cultura helenística que el emperador Juliano había reestablecido y cuyo centro seguían siendo los continuadores, cada vez más heterodoxos, de la Academia platónica de Atenas.

99 Cfr. HubEÑáa, Florencio. «Encuentro del Cristianismo con la Cultura Clásica», en: Polis. Revista de ideas y formas políticas de la antigüedad clasica. Universidad de Alcala de Henares, 1992 , p. $157 / 71$.

100 El término paganus o paganini, para designar a los seguidores de falsos dioses, no aparece en lenguaje corriente hasta el 365 (Du Cange. Gloss. ined. et infim. latinit. v. ${ }^{\circ}$ PAGANI. Edit. Didot, t. v, p. 8, col. 1) y formalmente se encuentra por primera vez en una ley de Valentiniano 1 del 17 de febrero del 368 o más exactamente del 370? (Cod. Theod. XVI, 2, 11: «Deonom falsorum cultores, quos usitato nomine paganos vocamus» (cit. San Agustin. Retract. II, 43). Pero en este texto el término no significa más que la gente de los pagi (distritos rurales) ... los paisanos o campesinos (GOTHOFREDI. Cod. Theod. edic. Ritter, t. VI, p. 51. MARTROYE, P. «La répreasion de la raagie et les culte des gentil\& au IV siècle», en: Revue historique de droit francais et etranger. 1930, p. 683, nota 1. El verdadero significado del uso del término surge del texto "pagani, it est gentile» y parece ser una simple extensión del concepto gentilis(Cfr. GréGorre, H. en: Nouvelle Clio, IV, 1952, 31). A comienzos del siglo IV se usaba para designar la infidelidad, parece haber sido sinónimo de gentilis que es la forma de traducir la palabra griega ethnikoi (Cfr. PIGANIOL, A. op. cit., p. 382). Anterionmente se usaba el término gentilis y en Oriente hellene. Para el uso del término cfr. ZELLLER, J. Paganus. Essai de terminologe historique. Paris, 1917; idem. «Paganus . Sur 1'origine de l'acception religleuse du mot». en: Comptes Rendus Acad Inscr. 1940, p. 526.

${ }^{101}$ Las Saturnales de Macrobio - del 400- eran clara expresión de este paganismo: «son la justificación más solemne de la teología solar»s/ TURCHI. H. La religione di Roma antica. Bologna, Capelli, 1939, p. 306.

Hispania, del Mediterráneo al Atlántico

Hispania Sacra 51 (1999) 
Las medidas persecutorias contra este culto tradicional romano comenzaron con los hijos de Constantino. «Una ley de Constante del 341 establecí́ que la superstición ha de cesar y la insensatez de los sacrificios a los dioses debe ser penada». Al año siguiente se decretó la abolición de los sacrificios, pero la medida debio ser suspendida en el 342 por chocar con una violenta oposición. Costancio también ordenó, en el año 353, la clausura de los templos de todo el Imperio, amenazando con la pena capital a cualquiera que osara seguir sacrificando (Cod. Theod. X. 2) ${ }^{102}$. Estas leyes de Constancio y Constante fueron tan implacables que Libanios habla de una «espantosa tempestad», pero su cumplimiento fue muy relativo. Sabemos por Símaco que durante los primeros años del gobierno de Graciano (hasta el 380) «el culto continuaba siendo celebrado como en otro tiempo ... todos los sacerdotes están en su puesto, los pontifíces se reúnen en los días designados, los arúspices observan los prodigios, las vestales mantienen el fuego sagrado ${ }^{103}$.

Pero la modificación de esta política está vinculada directamente con el acceso al trono del hispano Teodosio y sus medidas contra las herejías, que analizamos precedentemente.

En cuanto al «paganismo» Teodosio promulgó un edicto en Constantinopla el 21 de diciembre del $381 » 104$, por el que ponía fin a la política tolerante de Joviano y Valentiniano I y se condenaba el participar en sacrificios diurnos o nocturnos o usar para tal propósito cualquier altar o templo existente (Cod. Theod. XVI, 10, 7) ${ }^{105}$. Su aplicación fue ratificada por otro edicto fechado el 30 de noviembre del 382, referido al culto en Edessa, donde se expropiaban los templos y sus tesoros (incluyendo las estatuas de los dioses) y se prohibía el acceso a los altares (Cod. Theod. XVI, 10, 8) ${ }^{106}$ Así la ley citada -presumi-

102 Cfr. GRISAR, Hartmann. Roma e le fine del mondo antico. Roma, Desclee, 1943, t. I, p. $10 / 1$.

103 BoIsSIER, Gastón. El fin del paganismo. Madrid. Jorro, 1908, t. II, p. 274.

104 Señala Marta Sordi que la definición de cumplir actos de culto pagano como vesanus aparece en el edicto de Tesalónica (Cod. Theod. XVI, 1, 2) (dementes vesanosque) del 27 de febrero del 380 (ver post) y aunque este edicto culpa especialmente a los herejes, resguarda cunctos populos quos clementiae nostrae regit temperamentum a todos los súbditos del Imperio, esto es implícitamente también a los paganos (SORDI, Marta. L'atteggiamento di Ambrogio di fronte a Roma o al paganesimo. en. Ambrosius episcopus. Atti del Congresso Intemazionale di studi ambrosiani nel XVI Centenario della elevazione di sant'Ambrogio alla cattedra episcopale. Milano, Vita e Pensiero, 1976, t. I, p. 220).

105 Los emperadores Graciano, Valentiniano y Teodosio Augustos a Floro, Prefecto del Pretorio. Si alguien, insensato y sacrilego, se mezcla en sacrificios prohibidos diurnos y nocturnos como consultor de cosas inciertas; y si cree o piensa que hay que ir a algún santuario o templo para hacer estos delitos; sepa este hombre que será sometido a proscripción, puesto que nosotros mandamos que Dios sea venerado de modo legítimo y con tantas súplicas, y no profanado por dementes encantamientos. Dado en Constantinopla el 21 de diciembre (?), bajo el consulado de Euquerio y Siagrion.

106 Los mismos Augustos a Paladio, Jefe de Osdrone. Con la autoridad del consejo público, determinados que aquel templo muy frecuentado y común al pueblo, en el que haya estatuas valoradas 
blemente mal fechada según De Giovanni- parecía condenar solo los templos donde se reunían para hacer oráculos; decísión que admitía una apelación y el Senado de Constantinopla obtuvo un edicto de noviembre del 382 que evitaba cerrar los templos que eran lugares de paseo y permitía se admirasen sus obras de arte. Esta disposición, fechada en Constantinopia y dirigida a Palladio, dux Osdroenae, permitía que se mantuviera abierto el templo de dicha región (probablemente el de Edessa), para que pudieran ser apreciados sus objetos por el valor de su arte y no porque tengan algo de divino (artis pretio quan divinitate metienda). El emperador quería que continuaran las visitas al templo y autorizaba fuera lugar de reunión de las asambleas; pero de ninguna manera, debía poder suponerse que, bajo el pretexto del acceso al templo, se permitía el cumplimiento de sacrificios prohibidos» ${ }^{107}$.

Como observa De Giovanni «un problema particularmente delicado que se presentaba al legislador era la suerte que debía reservarse a los templos paganos. En la ciudad, estos santuarios constituyeron por siglos el centro, el punto de referencia de la vida pública; en ellos se desarrollaron asambleas populares y el culto de los dioses en los momentos más críticos de la historia patria. A su vez, los templos eran edificios ricos en obras de arte y ornamentación admirable, que sería muy inoportuno destruir. También en la campaña los santuarios eran numerosos; refiriéndose a estos últimos, Libanios afirma que ellos son «el alma de la campaña, los primeros edificios construidos en el campo y junto con nosotros atravesaron muchas generaciones» (oratio XXX, 9). Destruyendo los templos - dice ahora Libanios- la campaña está perdida, el coraje de los ciudadanos desaparece junto con su esperanzas (Oratio XXX, 10). La intervención del legislador era más necesaria, en el curso del siglo IV, en la medida que se producían alrededor de los templos disputas violentas entre cristianos y paganos. Ocurría así que obispo y monjes de temperamento belicoso, funcionarios enérgicos y muy celosos no perdían ocasión para destruir los santuarios» ${ }^{108}$.

Pero a partir del siglo $\mathrm{V}$ la mayoría de los templos dedicados al culto pagano fueron cerrados y abandonados contribuyendo a la ruina edilicia de la Roma medieval ${ }^{109}$. Una disposición de Honorio del 408 los convirtió en bienes

\footnotetext{
más por su arte que por el culto a las divinidades, continúe abierto permanentemente y que ningún oráculo furtivo obstaculice esta decisión. Tu experiencia, celebrada por los deseos de todos y confirmada por nuestra autoridad, permitirá que el templo del oráculo quede abierto, pero de tal modo que con este ingreso no se piense que se permite práctica alguna de sacrificios prohibidos. Dado el $\mathbf{3 0}$ de noviembre en Constantinopla, bajo el consulado de Antonio y Siagrio».

${ }^{107}$ Cfr. De GlovanNi, L. op. cit. p. 132/3.

108 Idem p. 130/2.

109 GRISAR, H. op. cit., t. 1, p. 20 ss.
}

Hispania, del Mediterráneo al Atlántico Hispania Sacra 51 (1999) 
del estado y evitó su destrucción, no así la de sus altares ${ }^{110}$. Por otra parte, ya en el siglo IV, el papa Dámaso erigí junto a la cerca del templo de los Arvales un oratorio cristiano con una gran inscripción dedicada a santa Beatrix y a sus hermanos mártires, perseguidos por Diocleciano ${ }^{111}$.

Paralelamente Teodosio adoptó medidas contra los apóstatas, mediante sucesivas leyes promulgadas el 2 de mayo del 381, el 21 de mayo del 382 y el 21 de mayo del 383 (Cod. Theod. XVI, 7, 1, 2 y $3^{112}$ que les quitaban el derecho de testar (ius testandi) y consecuentemente fueron privados de heredar ${ }^{113}$ los cristianos que se hicieran paganos ${ }^{144}$.

Así como el cristianismo había sido perseguido por considerarse legalmente una religio illicita ahora se aplicaba igual status a los cultos tradicionales, convertidos en una superstitio que debía ser extirpada.

Sin lugar a dudas las medidas del basileus Teodosio fueron sistemáticas. En el 382 dispuso la supresión del título de pontifex maximus, que ya había abandonado formalmente su colega Graciano, así como una nueva retirada de la diosa Victoria del Senado ${ }^{115}$.

Por ley del 25 de mayo del 385 se renovó la antigua campaña contra la adivinación - vinculada a la magia perseguida por todos los integrantes de la

\footnotetext{
110 Como vimos Teodosio ya había dispuesto conservar como museo un templo de Edessa (Cod. Theod. XVI, 10, 8).

111 GRISAR, H. op. cit., t. 1, p. 24.

112 La XVI, 7, 3 del 383, publicada en Padua, habría sido — según Biondi- el inicio de la hucha de Graciano contra los paganos. (Biondi, B. op. cit., p. 332)

${ }^{113} \mathrm{Al}$ morir, todos sus bienes pasarian al fisco.

114 «Los Emperadores Graciano, Valentiniano y Teodosio Augustos a Eutropio, Prefecto del Pretorio. Mandamos que sea abolida la facultad y derecho de testar, a los cristianos que se hicieron paganos: y si hubiera tal testamento de algún difunto, que sea removida y rescindida esa condición. Constantinopla, VI nona milus, [2 de nayo] bajo el consulado de Siagrio y Euquerion (XVI, 7, 1); -Los mismos Augustos [Graciano, Valentiniano y Teodosio] a Postumiano, Prefecto del Pretorio. Quitamos a los cristianos y fieles que se volcaron a los ritos y cultos paganos toda potestad de establecer testamento en beneficio de cualquier persona, de modo que carezcan de derecho romanow (XVI, 7, 2), «Aquellos cristianos y simples catecúmenos que, despreciada la venerable religion, volvieron a los altares y templos, si tuvieren hijos o hermanos puros, esto es sucesion propia o legítima, seáles quitado el derecho de testar a su arbitrio en beneficio de cualquier personas (XVL, 7, 2, 1) y «La misma forma debe ser guardada, en lo que concierne a esas personas, respecto de las sucesiones. Fuera de las suyas propias y legítimas, que puedan corresponderles de los bienes de sus padres o hemanos puros, no tendrán, ni siquiera por juicio de voluntad establecida, ningún derecho de reclamar herencias. Además serán categóricamente excluidos no sólo de poder testar, sino también de alcanzar y hacer uso de herencias. Constantinopla XIII kalendas iunium [20 de mayo] bajo el consulado de Merobaudo, por segunda vez, y de Saturninon (XVI, 7, 2, 2).

Its Cfr. HUBEÑÁ, Florencio. El emperador Graciano... op., cit.
}

Hispania, del Mediterraneo al Atlántico Hispania Sacra 51 (1999) 
dinastía Valentiniana - prohibiéndose los sacrificios sangrientos con intención adivinatorio (Cod. Theod. xvi, 10, 9) ${ }^{116}$.

Pero las decisiones contra los cultos tradicionales fueron aplicadas con relativa intensidad y en muchos casos demoradas por intereses políticos circunstancíales o dificultades políticas del propio emperador. Pero esta situación cambió notablemente después de la penitencia de Teodosio en la Navidad del 390 , tras la masacre de Tesalónica ${ }^{117}$ que llevó al emperador a promulgar, el 18

116 «Los Emperadores Graciano, Valentiniano y Teadosio Augustos a Cinegio, Prefecto del Pretorio. Que ninguno de los mortales tenga la audacia de hacer un sacrificio, de tal modo que trate de recibir, por el examen del hígado o por el presagio de las entrañas, la esperanza de una vaga promesa $o$, lo que es peor, de conocer el futuro por medio de esa execrable consulta. Y en verdad, queda pendiente la amenaza de un suplicio mayor para aquellos que, en contra de la prohibición, intenten conocer la verdad de las cosas presentes o futuras. Dada el 25 de mayo en Constantinopla, bajo el consulado de Arcadio Augusto (por primera vez) y de Bauton (por quinta vez)".

117 En agosto (?) del 390 (PALANQUE, Jean-Rémy. Saint Ambroise et l'Empire romain. París, De Boccard, 1933. Apendice. III-39, p. 536/9. Para fechas: (op. cit. Apéndice III-39, p. 536/9) Teodosio, presuntamente inspirado por Ambrosio, publicó una ley que condenaba a muerte a los culpables de vicios «contra natura» (pederastia) (Collat. leg. Ron. et Mosaic. V, 3) y el magister peditum Buterico (Butheric) hizo encarcelar a un cochero del circo muy popular, provocando un motín de la poblacion de Tesalónica que incluyó el asesinato de Buterico, lapidado y arrastrado por las calles. Enterado Teodosio -recordando los incidentes de Antioquia del 387 y de Callinicon del 388- se encoleriz6 y ordenó un escarmiento a espada limpia entre la población convocada al circo («masacre») que duró siete horas, aunque luego revocó la medida (el 18 de agosto en Verona (Cod. Theod. IX, 40, 13), ya habian sido muertas tres mil personas (Sozomeno VII, 25, TEODORETO. Historia Ecclesiastica V, 17, 3, THEOPANOS. Chronographia 1, 113 y RuFiNo. Historia Eccleslastica XI, 18: «Teodosio, tuvo un acceso de ira al recibir el anuncio imprevisto de aquel hecho atroz y ordeno que el pueblo fuese invitado a los juegos del circo y después, de imprevisto, fuese rodeado de soldados con ordenes de degollar, sin distinción, a cualquiera que se tuviese adelante: era como establecer el derecho de venganza, no a los culpables, sino al furor» (RUFINo. Storia della Chiesa. Roma, Cittá Nuova, 1986, II, 18). El obispo Ambrosio reaccionó enviando varias cartas al emperador (XI y L $L$ ): «...El escándalo de Tesalónica es ya un hecho consumado. No existe memoria de cosa semejante. En lo que a el respecta tuve que limitarme a contemplar el mal sin poder remediar cosa alguna. O mejor dicho, no pocas veces imploré misericordia, advirtiendo que podría suceder algo terrible. Vos mismo os distéis cuenta de que se trataba de algo muy importante, puesto que mandasteis retirar la orden ... pero fue demasiado tarde. Por mi parte no disimulé la seriedad del asunto ni disminuí su contenido. cuando lleg6 aquí la noticia, se celebraba una conferencia de obispos en la que intervenían pastores de las Galias. Ninguno de ellos disimuló su enojo ni os perdonó por el mero hecho de que eran amistosas vuestras relaciones con Ambrosio ... No escribo estas cosas para avergonzaros, sino para aninaros con la consideración del ejemplo de santos reyes, a fin de que borreis la mancha que ha caído sobre vuestra dignidad imperial. Vos la lavaréis con vuestra humillación ante el Señor ... Os aconsejo, os ruego y también os amonesto y advierto; muy grande es mi pena al veros impasible ante la muerte de tantos inocentes. Vos que hasta hoy habíais sido modelo de piedad y que os distinguíais entre los príncipes por vuestra mansedumbre. Mis preferencias por vos han sobrepasado a las que tuve para con muchos Emperadores: sólo a uno (Graciano) pude comparar con Vos. Todavía no quiero echaros en cara la dureza de vuestro corazón; pero os digo desde ahora con verdadero temor; no me atrevo a ofrecer el sacrificio, si vos estais presente. Ello serfa vedado por el asesinato de uno solo, cuanto más ante la mortandad de la 
de agosto del 390 en Verona, una ley que establecía que las sentencias imperiales que dispusiesen penas graves, fuesen diferidas para su ejecución, treinta días, para permitir actuar a la piedad» ${ }^{118}$.

Además, con el tiempo se acentuaron los rasgos más activos en la política de unidad encarada por Teodosio. En ello parecen haber influido, por un lado el obispo Ambrosio, que asumió un papel fundamental como «consejero» del basileus y, por otro, el franco Rufino (Rufinus) y sus partidarios hispanos y aquitanos que cumplieron un papel firme en las paces entre el emperador y el obispo, y lograron defenestrar al prefecto pagano Tatiano (Flavius Eutolmius Tatianus), imponiendo su política pro-goda y pro-católica ${ }^{119}$.

A partir de este momento «el paganismo será demolido pieza por pieza» y sus cultores «excluidos de la comunidad de los hombres» ${ }^{120}$

Ambrosio usó toda su influencia contra la religión de los «demonios» y como resultado el 24 de febrero del 391 fue firmado en su misma sede de Milán el primer edicto formal de proscripción del paganismo (Cod. Theod. XVI,

que os habéis hecho responsable. Lo que sigue escribolo de mi propio pufio y letra, y sólo a Vos estŕ destinado ... El Seffor nos conceda que la presente cuestión se resuelva pacíficamente. Dios nos amonesta de muchos modos: por signos sobrenaturales, por la voz de los profetas; y aun por visiones de humildes pecadores, se digna adoctrinarnos. Roguemósle, pues, que detenga la guerra y que a los jefes del Estado os conceda la paz. Conserve la traquilidad y la fe de su santa Iglesia; pero, para eso, se necesita un Emperador que sea cristiano y piadoso ... La hora de vuestro sacrificio ha llegado. Es decir, la hora en que vuestros dones sean aceptables». Sobre las fechas cfr. PALANQUE, Jean-Rémy. Saint Ambroise et l'Empire romain. Paris, De Boccard, 1933. Apéndice II-3, p. 468. Finalmente le apartó de la comunión cristiana hasta que hiciese penitencia pública (cfr. TEODORETO. Historia ecclesiastica V, 17 y DX, 30) AMBRosio. Epist. $L$. De obitu Theodosii 28-34; AGUSTIN. Civ. Dei. V, 26 y PAULINo. Vita Ambrosii XXIV).

118 Cfr. Rufino 11, 18), «Si alguno se permite por imprudencia desgarrar nuestro nombre con términos malévolos e inconsiderados, y se hace por orgullo detractor turbulento del tiempo presente, prohibimos que se le imponga ningún castigo ni mal tratamiento, si la ofensa proviene de la ligereza conviene despreciarla; si de la locura, compadecerla; si de la perversidad, perdonarias (Cod. Theod. $\mathrm{XX}, 7,1)$. Los historiadores seĩalan que Teodosio vacilo varias semanas -n que hubo negociaciones secretas (Epist. LI) por intermedio del magister officionum Rufino- pero al final se sometió a la penitencia publica en la Navidad del 390 (octubre-diciembre del 390, hasta la Navidad). La famosa relación de Teadoreto (Hist. eccl. V, 17/8 que detalla Palanque (op. cit., p. 245, nota 1) segin la cual Ambrosio prohibió al emperador la entrada a la iglesia, es totalmente legendaria. Asimismo segrin Paredi (op. cit. p. 414) muchos historiadores ven en la ley del 13 de agosto del 390 (Cod. Theod. IX, 40, 13) la penitencia impuesta por san Ambrosio a Teodosio). «Esta penitencia de Teodosio es un acontecimiento capital en la historia de la iglesia y en la del imperio... La arbitrariedad monárquica fue desarmada por la autoridad moral de los pontífices» (PALANQUE-BARDY-LABRtolle. op. cit. t. III, p. 512). Luego Teodosio afirmaría «S6́10 Ambrosio me ha hecho ver qué es un obispo».

II9 La situación de Tatiano se complicó por su mediacion entre el joven Augusto Arcadio y la bella Gala, que se odiaban. En 390 Arcadio echó a Gala del palacio (Chron. Minor. II, 62), provocando urgente regreso de Teodosio a Constantinopla en julio del 391.

${ }^{120}$ ALLARD, Paul. Le christianisme et l'Empire Romain. Paris, Lacoffre, 1925, p. 267. 
$10,10)^{121}$ dirigido al prefecto Albino. Por éste quedaba prohibida toda ceremonia exterior de culto en la ciudad de Roma - sacrificios, visita de templos, homenajes a los ídolos divinos-y pesadas amenazas recaían contra los funcionarios que no observaran la ley ${ }^{122}$

Un edicto fechado el 11 de mayo del 391 privó a los apóstatas de todos los derechos civiles y políticos (Cod.Theod. XVI, 7, 4 y 5 y XI, 39, 11) ${ }^{123}$.

A su vez el 16 de junio del mismo año, desde Aquileya, ante los disturbios provocados por el pueblo de Alejandría, Teodosio dispuso mediante un edicto dirigido a Evagrio, praefectus augustalis et romanus comes Aegypti, la inter-

121 \&Los mismos Augustos [Valentiniano, Teodosio y Arcadio] a Albino, Prefecto del Pretorio. Que nadie se manche con victimas, que nadie mate una inocente víctima, que nadie vaya a los sannurios, recorra los templos o contemple simulacros creados por obra mortal, para no hacerse reo de sanciones divinas y humanas. Que a los jueces se aplique también la norna siguiente: si alguno entregado a ritos profanos entrare a un templo para adorar, ya sea de camino o en la ciudad, sea obligado a pagar al punto quince libras de oro; y su personal debera pagar con la misma celeridad suma semejante, a no ser que se haya opuesto al juez y lo haya manifestado con testimonio público. Los varones consulares deberán pagar seis libras de oro, y del misno modo su personal; los correctores y los presidentes, cuatro, y su servidumbre se ajustaráa a la misma norma. Milán VI kalendas martius [24 de febrero], bajo el consulado de Taciano y Símacon.

122 El hecho de que el lider del paganismo, Flaviano, a causa de su posición oficial, debiera aplicar la nueva ley, añadía el insulto al daño (BLOCH, Herbert. «EI renacimiento del paganisno en Occidente a fines del siglo IV», en: Momigliano, A. y otros. El conflicto entre el paganismo y el cristianismo en el siglo N. Madrid, Alianza, 1989, p. 212).

123 «Los Emperadores Valentiniano, Teodosio y Arcadio Augustos a Flaviano, Prefecto del Pretorio. Aquellos que traicionen la santa fe y profanen el bautismo sean separados de la suerte común; y queden, como ya antes habíamos sancionado, fuera de todo testimonio y derecho de hacer testamento y de suceder a alguien en herencia. Tampoco podrán ser inscriptos como herederos. Incluso mandaríamos que fueran arrojados lejos de aquí, si no nos pareciera mayor castigo el que permanezcan entre los hombres y carezcan de humano auxilio» (XVI, 7, 4), «Aquellos que mancharon la fe consagrada a: Dios y, traicionando los divinos misterios, abrazaron lo profano, nunca volverán a su antiguo estado. La maldad de sus costumbres no la anulará ninguna clase de ayuda ni sutil defensa. No es posible que defiendan lo falso y fingido. En efecto, puede socorrerse a los caldos y vagabundos, pero no puede haber arrepentimiento, a menudo ayuda en otros delitos, para los perdidos; esto es para quienes profanan el santo bautismo. Concordia, 5 idus maius [27 de abril], bajo el consulado de Taciano y Simaco (XVI, 7, 4, 1); «Los mismos Augustos [Valentiniano, Teodosio y Arcadio] a Flaviano, Prefecto del Pretorio. Que desaparezca todo esplendor de dignidad, incluso por nacimiento, en aquellos que, alejados de la fe y enceguecidos en su mente, se desviaron del culto y la reverencia a la religión sacrosanta y se entregaron a los sacrificios; de modo que sean bajados de su estado y sean objeto de perpetua infamia, y ni siquiera sean contados entre la última bajeza del valgo. En efecto, ¿qué pueden tener de común con los hombres ellos, quienes en sus mentes siniestras y nefastas menosprecian la gracia de la comunión y se separaron de los hombres. Concordia 5 idus maius [11 de mayo], bajo el consulado de Taciano y Símaco (XVI, 7, 5).

Hispania, del Mediterráneo al Atlántico

Hispania Sacra 51 (1999) 
dicción del culto pagano en Egipto (Cod. XVI, 10, 11) $)^{124}$ y la destrucción del famoso Serapeion ${ }^{125}$.

De este modo «las dos ciudadelas del paganismo, Roma y Alejandria, fueron alcanzadas por dos leyes especialmente dirigidas contra ellas» ${ }^{126}$.

Finalmente el 8 de noviembre de 392 fue promulgada una ley que «la historiografía moderna ha considerado como la sentencia de muerte contra el paganismo» ${ }^{127}$. Por ella no solo se reitera la prohibición de sacrificar víctimas y examinar sus entrañas, sino se amplia a cualquier tipo de sacrificio: fuego en honor a los lares, libaciones de vino al genius, ofendas a los penates, quemar incienso, colgar guimaldas en los altares. Por otra parte, no se contenta con cerrar los templos, sino que avanza prohibiendo altares en las casas y amenaza con confiscar aquellas de las que surja humo de incienso. Asimismo efectúa un cuidadoso detalle de castigos que incluyen a los funcionarios del Imperio (Cod. Theod. XVI, 10, 2) ${ }^{128}$.

\footnotetext{
124 «Los mismos Augustos [Valentiniano, Teodosio y Arcadio] a Evagrio, Prefecto Augustal, y a Ronano, conde de Egipto. No se conceda a nadie potestad de sacrificar, que nadie recorra templos, que nadie venere santuarios. Sepan y reconozcan que nuestra ley les impide el acceso a estos lugares profanos, a tal punto que, si alguien intentare algo prohibido en relación con los dioses, no le cabrá ninguna clase de perdón. Incluso si un juez confiado en el privilegio de su poder administrativo, entrare sacrílego en esos lugares manchados, deberá pagar quince libras de oro. Su personal deberá llevar igual suma a nuestro erario, a no ser que se haya opuesto al juez con la fuerza. Aquileya 16 kalendas iulius [16 de junio], bajo el consulado de Taciano y Ś́macow.

${ }^{125}$ El obispo Téfilo (Theophilus) de Alejandría, que era un ambicioso sin escrúpulos que gobernaba monárquicamente su poderosa diócesis (s/PAREDi, A. op. cit., p. 424) quiso convertir en Iglesia un templo consagrado a Dionisos que el emperador había donado. Encontró en el templo pagano requisado legalmente una serie de «rid́́culos» objetos de culto que exhibi6 en la plaza pública, ofendiendo a los <paganos> que reaccionaron violentanente matando a varios cristianos. Los paganos se rebelaron y el Serapeion se convirtió en su ciudadela; el filosofo Olympios les exhortaba a morir por su religión. Teodosio envió la orden de derribar el templo. Una noche, Olympios oyó salir del templo el canto del Alleluia y renunció a la defensa. Téfilo ordenó usar el hacha sobre la estatua; se decía y créra que entonces un terremoto baría descortezar el mundo pero solo escaparon del f́dolo una legion de ratas (topos). En aquella ocasión fue saqueada la biblioteca del Serapeion mientras era quemada la estatua del dios en el anfiteatro, entre los clamores de la plebe (Socrates V, 16; Sozomeno VII, 15; Theodoreto V, 22; Eunapio. Vita Sophisti 472. Cfr. Piganiol, A. op. cit., p. 259 y Paredi, A. op. cit., p. 484.

126 PALANQUE, Jean-Rémy. op. cit., p. $251 / 2$.

127 PIGANIOL, A. op. cit., p. 258.

128 «Los emperadores Teodosio, Arcadio y Honorio Augustos, a Rufino, Prefecto del Pretorio. Que ninguna persona, cualquiera sea su origen social o el orden a que pertenezca o su dignidad, bien esté en el ejercicio de algún cargo o lo haya ejercido antes, bien sea noble de nacimiento o humilde por su origen, condición social o fortunas, ofrezca en sacrificio en ningún lugar ni en ninguna ciudad una víctima inocente a imágenes carentes de sentido, ni venere, en expiación secreta, a su Lar con fuego, a su Genio con vino, a sus Penates con incienso, ni les encienda luces, ni les ofrezca incienso ni les cuelgue guirnaldas. Si alguien osara inmolar una víctima para un sacrificio, o consultara las entrafias palpitantes, será denunciado como persona incursa en delito de lesa majestad -y esta acusación
} 
De todos modos cabe observar que la desaparición del paganismo no fue tan sencilla; éste se negaba a desaparecer. No debemos olvidar que mientras la elite dirigente de Constantinopla estaba integrada por parvenus surgidos de las dificultades que tuviera el basileus Constantino en Roma y que favorecieran su traslado a esta ciudad, donde integraban el nuevo ordo senatorial -formado por todos los clarissimi (exfuncionarios) que entraban de oficio en esta clase semi-numerosa y muy jerarquizado, pero no por ello integraban el Senado«el Senado de Roma, en cambio, estaba formado esencialmente por una minoría de senadores hereditarios, integrantes de familias aristocráticas, inmensamente ricas y que fundaban su prestigio social sobre sus extensos bienes territoriales cultivados por ejércitos de colonos y esclavos», «el prestigio "religioso y cultural" muy disminuido de Roma recaía sobre ellos». "Se erigieron en guardianes de la tradición romana y de la religión del estado pagano», como también de los créditos oficiales y prebendas vinculadas a los cultos del estado ${ }^{129}$. Símaco (Quintus Aurelius Symmachus) —uno de sus dirigentes más notorios- «se creía regresado a los tiempos en que el Senado dirigía la política de Roma y él se hacía así la ilusión de participar en el gobierno del Imperio» ${ }^{30}$.

La rebelión del emperador Eugenio (Flavius Eugenius), apoyado por la aristocracia romana guiada por Flaviano (Virius Nicomachus Flavianus) fue uno de sus últimos estertores después del fracaso de Juliano «el apóstata» me-

\begin{abstract}
la podrá hacer cualquiera y recibira la condena apropiada, incluso si no intentaba descubrir nada contrario o referente a la vida de los emperadores--. Es suficiente para constituir un gran crimen que alguien desee echar abajo las leyes de la propia Naturaleza, investigar asuntos prohibidos, revelar secretos ocultos, tratar de efectuar prácticas prohibidas, intentar conocer el final de la vida del otro o provocar la esperanza en la muerte de otra persona. 2. Si alguien venerara, colocando incienso ante ellas, imágenes, hechas por el trabajo de los mortales y destinadas a padecer el paso del tiempo, llevado repentinamente por un temor ridículo hacia las efigies que él mismo ha creado, vendara un árbol con cintas, erigiera un altar de césped desenterrado por él mismo, $o$ intentara honrar vanas imágenes, ofreciendo un don aunque sea humilde, lo que constituye así con todo un total ultraje contra la religión, tal persona, como culpable de violación de la religión, será castigada con la perdida de la casa o propiedad en la cual se ha probado que llevó a cabo una tal superstición pagana. Por tanto decretamos que todos los lugares sean anexionados a Nuestro fisco, si se prueba que ellos han humeado con el vapor del incienso, siempre que se haya probado que tales lugares pertenecían a los que quemaron el incienso. 3. Es Nuestro deseo que esta disposición sea hecha respetar tanto por los jueces como por Ios «defensores» y curiales de las distintas ciudades, que los hechos descubiertos por ellos sean inmediatamente denunciados a los jueces y sean castigados por éstos. Por otra parte, si éstos opinasen que los defensores y curiales han ocultado algo por favoritismo o lo han pasado por alto por negligencia, serán sometidos a juicio. Por su parte, si los jueces, una vez avisados, pospusieran el castigo por negligencia, serán multados con treinta libras de oro y sus ayudantes se verán sometidos a la misma multa. Dada el sexto día de los Idus de noviembre (8 de noviembre) en Constantinopla, siendo cónsules Arcadio Augusto, por segunda vez, y Rufino (392).

129 PASCHOUD, Francois. Roma aeterna. Institut Suisse de Roma, 1967, p. 71 y p. 86.

130 Cfr. Epist. IV, 5. PANCHOUD, F. op. cit., p. 97.
\end{abstract}

Hispania, del Mediterráneo al Atlántico

Hispania Sacra 51 (1999) 
dio siglo antes. Delegaciones del Senado romano insistieron entre el 384 y el 392 , en más de cuatro oportunidades mediante delegaciones ante los sucesivos emperadores, para restaurar el altar de la Victoria en el Senado y lograr la restitución a los colegios sacerdotales romanos y a los templos de los bienes confiscados por Graciano en el 382.

Pero la derrota del «usurpador» Eugenio el 5 y 6 de setiembre del 394, bajo el signo de la cruz - a la manera de Constantino- en fluvius Frigidus ${ }^{131}$ signi- $^{-}$ ficó la derrota del paganismo. Como las tropas de Teodosio fueron favorecidas por un huracán, el poeta Claudiano escribi6: «Tú eres el emperador amado por Dios sobre todas las cosas ... por quien incluso el éter combate y a cuyas banderas los vientos acuden a raudales» ${ }^{132}$.

A partir de esta victoria, los templos no se convirtieron en caballerizas como amenazaron Eugenio y su ideólogo pagano Flaviano, en Milán, antes de la batalla, sino Teodosio fue saludado por el obispo Ambrosio como christianissimus princeps concluyendo su operativo de demolición del «paganismo» ${ }^{133}$.

Después, los paganos se contentaron con la práctica furtiva de sus ritos y con alimentar los sueños apocalípticos de la vuelta de los viejos dioses» ${ }^{134}$.

Paralelamente se reformó el antiguo calendario romano basado en las festividades paganas, muchos de sus templos perdieron su sentido sacro, otros fueron adaptados al cristianismo -inclusive el 25 de diciembre, festividad del nacimiento del Sol Natalis Invictus pasó simbólica y convencionalmente a partir del siglo IV a celebrarse como Navidad-, otros, en cambio, fueron destruídos; parece que fueron víctimas de esa destrucción el templo de Vesta, —depositario y custodio del fuego sacro y por ende, de la más arcana tradición- y la casa de las Vestales, dos de las primitivas construcciones religiosas de Roma; otros, simplemente, quedaron olvidados, sepultados en el sueño de los siglos, tal fue la suerte del Ara Pacis (altar de la paz) construido en los albores del imperio» ${ }^{135}$.

La nueva legislación marcó el fin del paganismo, cuyos estertores se refugiaron en sus casas de campo y en las villas (pagi). Un ejemplo claro de esta

${ }^{131}$ Haindenschaft, hoy Vipava <Wippach $>$ en Yugoslavia, afluente del Isonzo.

${ }^{132}$ Cit. MAIER, Franz Georg. "Las transformaciones del mundo mediteráneo. Siglos IIIVIII", en: Historia Universal Siglo Veintiuno. Madrid, Siglo XXI, 1972, p. 113.

${ }^{133}$ Epístola I. Biondi menciona la existencia de alrededor de 150 leyes desde Constantino a Teodosio bajo los títulos V-XI del libro XVI del Código teodosiano (BIONDI, B. op. cit, t. I, p. 260).

134 JONES, A.H.M. «El trasfondo social de la lucha entre el paganismo y el cristianismo», en: Momigtiano, A. y otros. El conficto entre el paganismo y el cristianismo en el siglo IV. Madrid, Alianza, 1989, p. 46. San Agustín afirma que Flaviano puso en circulación un oráculo que predecía el fin del cristianismo para tantos años tras su inicio como días tiene el afio (De Civ. Dei. XVII, 53. Cfr. RuFINO. H. E. XI, 33) Si ponemos la crucifixión en el 29 d. C. y si se cuentan 365 affos desde la fecha llegamos al año 394 para este dies irae pagano» (Bloch, R. op. cit., p. 215).

${ }^{135}$ Cfr. Cochrane, Charles N. Cristianismo y culuura clásica. México, F.C.E, 1992, p. 325/6. 
situación la hallamos en las Galias y se aprecia claramente en la prédica del obispo Martín de Tours, relatada por Sulpicio Severo. Ahora, las antiguas divinidades (lares, genius) se convirtieron en demonios (omnes dii gentiun daemonia), como ya desde siglos decían los cristianos recitando los salmos davídicos: todos los dioses de los gentiles son demonios» ${ }^{136}$.

Poco más tarde por leyes del 23 de marzo del 395 (Cod. Theod. XVI, 2 , $29)^{137}$ y del 23 de enero del 397 (Cod. Theod. XVI, 2, 30 y XI, 16, 21/2) que mencionan expresamente los privilegios del obispo de Roma, el Imperio se proclamó formalmente protector de la Iglesia ${ }^{138}$. Honorio pronunció solemnemente que «todos los edictos de nuestros predecesores referidos a las santas iglesias subsistirán sin violación y sin modificación ${ }^{139}$.

A la muerte de Teodosio su hijo Arcadio, el 7 de agosto del 395 renov6 las medidas «que prohiben el acceso a los templos y a los sacrificios y ordena, en consecuencia (igitur), a todo el mundo, bajo sanción de penas corporales y pecuniarias previstas por la ley, de convertirse a la religión católica y lo confirma con decretos contra los heréticos y paganos ${ }^{140}$. A su vez el 7 de diciembre del 396, los sacerdotes o hierofantes eran despojados de sus últimas inmu-

\footnotetext{
136 Cfr. PAREDI, A. op. cit., p. 485.

137 «Los emperadores Arcadio y Honorio Augustos a Hierio, vicario de Africa. Todo lo que ha sido establecido en diversas épocas por nuestros antepasados, ordenamos que permanezca inviolable e incorrupto, en lo que a las sacrosantas iglesias se refiere. Por tanto, nada sea modificado de sus privilegios, y a todos los que están al servicio de las iglesias les sea dada una protección, porque en nuestros tiempos deseamos que se añada más reverencia, más bien que se modifique algo de lo que habia sido concedido en otro tiempo. Dado en milán a $X$ kalendas aprilis [ 23 de marzo], bajo el consulado de Olibrio y de Probino» (XVI, 2, 29).

138 «Los mismos Augustos [Arcadio y Honorio] a Teodoro, prefecto del Pretorio. Después de otras recomendaciones se agrega: en la presente orden no prescribimos nada nuevo, antes de que afirmemos aquellas cosas que parecen perdonadas en otro tiempo. Por tanto, prohibimos reducir los privilegios que alguna vez obtuvo la reverencia debida a la religión, incluso bajo amenaza de castigo, de modo que también aquellos que obedecen a la Iglesia gocen de los mismos beneficios que la Iglesia. Dado en Milan prid. kalendas februarius [31 de enero] bajo el consulado de Cesario y de Atico\% (XVI, 2, 30 del 397); «Los mismos Augustos a Teodoro, prefecto del Pretorio. No conviene que sean disminuidos los privilegios de la venerable Iglesia, que concedieron los divinos príncipes. Por tanto, que una inviolable observancia custodie las cosas que atañen al Obispo de la ciudad de Roza, de tal modo que la Iglesia esté al margen de cualquier obligación supletoria o de cualquier sórdida función. Dado el 31 de enero en Milán, bajo el consulado de Cesario y Atico» (XI, 16, 21) y «Los mismos Augustos a Teodoro, prefecto del Pretorio. No permitimos que sean disminuidos los privilegios de la venerable Iglesia, de tal modo que las Iglesias estén al margen de cualquier obligación supletorio o de cualquier sórdida función. Por tanto todo lo que obtuvo la reverencia de la religión por los antiguos preceptos, prohibimos también, bajo amenaza de castigo, que sea recortado: de tal modo que también aquellos que obedecen a la Iglesia gocen de los beneficios que están previstos. Dado el 12 de junio en Milán, bajo el consulado de Cesario y Atico» (XI, 16, 22).

139 PALANQUE-BARDY-LABRIOLLE. op. cit., p. 523.

140 MARTROYE, P. op. cit., p. 699.
}

Hispania, del Mediterráneo al Atlántico Hispania Sacra 51 (1999) 
nidades (Cod. XVI, 10, 14) ${ }^{14 !}$. Por ley del 15 de noviembre del 407, dirigida por Honorio a Curtius, prefecto del pretorio de Italia, se suprimieron las annonae que servían para pagar los sacrificios y los juegos rituales. Las estatuas de templos fueron retiradas. Los edificios mismos, sea en las ciudades sea en los oppida, fueron destinados al uso público ${ }^{142}$.

«La antigua religión desaparecía lentamente, poco a poco, y solo treinta años después de la ley que la suprimía por completo, decía Teodosio II que creía que no quedaban más paganos en el Imperio (paganos qui supersunt "Cod. Theod. XVI; 10, 22")»143. Hoy sabemos que aún quedaban y preocupaban porque, en ese momento mismo, Agustín de Hipona escribía la Ciudad de Dios para defenderse de sus críticas apocalípticas.

La cuestión del paganismo debió preocupar notablemente a los primeros obispos que aconsejaban al poder político, ante la nueva situación que significa el compromiso de la Iglesia con el Imperio y la misión de evangelización que tenían asignada. Para ellos no quedaban dudas que los paganos inflexibles eran un verdadero peligro social para la nueva sociedad que se anhelaba construir (la civitas Dei, la Cristiandad) y en tal sentido debían ser convertidos (para salvarlos) o anulados (para que no obstaculizaran). En este aspecto coincidían con el proyecto político imperial de la pax romana convertida en pax christiana.

Como señala Biondi «nuestra apreciación puede variar al infinito, según nuestras ideas de hombres modernos, o según la experiencia histórica posterior. Pero es históricamente seguro que la ley fue invocada, alabada y bendecida por toda la Iglesia de su tiempo, considerada como la expresión de aquella colaboración entre Estado e Iglesia, que respondía a la conciencia universal, si exceptuamos algún nostálgico pagano o algún ambicioso hereje. La sociedad de entonces no reclamaba libertad religiosa sino afirmación de la fe cristiana» ${ }^{144}$.

Por otra parte para analizar la política persecutoria que hoy -con mentalidad anacrónica de «derechos humanos» llamamos intolerante- no debemos

141 «Los mismos Augusto [Teodosio, Arcadio y Honorio] a Cesario, Prefecto del Pretorio. Si fueron concedidos, en virtud de derecho antiguo, algunos privilegios a sacerdotes, ministros, prefectos, hierofantes o cualquier otro nombre que tengan, que sean éstos abolidos por completo, y que no se alegren más de estar munidos de privilegios; sus actividades ya se sabe que están condenadas por la ley. Constantinopla VII idus decembren [ 7 de diciembre], bajo el consulado de Arcadio por cuarta voz y de Honorio por tercera vez, Augustos» (XVI, 10, 14).

142 Cfr. LAMOTTE, J. «Le Mythe de Rome «Ville Esternelle» et saint Augustin», en Agustiniana, 11,1961, p. $248 / 9$.

143 BOISSIER, G. op.cit., t. II, p. 314.

144 BIONDI, B. op. cit., t. I, p. 307. 
olvidar que «como fue observado por Cracco Ruggini ${ }^{145}$ entre el 383 y el 390 la aristocracia pagana, social, cultural y económicamente aguerrida, combatía su propia batalla, en la esperanza de consolidar su poder, con armas apologéticas que eran en buena parte comunes con las que usaban arrianos y hebreos. Los tres partidos se encuentran alineados ideológicamente. Los tres ponen el acento en la eficacia de la tradición y en la oportunidad de conservarla íntegra, pero apelando a razones diversas» ${ }^{146}$. Y, además, establecían peligrosas alianzas políticas; el enemigo existía y estaba claramente perfilado.

El emperador, preocupado por la aplicación de sus disposiciones, al no disponer de un eficiente aparato represivo, dejaba una amplia iniciativa punitiva a la autoridad local. La falta de celo de ésta motivó la repetición de las normas legales (Cod. Theod. XVI, 1) y las amenazas a los funcionarios poco responsables; como también se dejaba a los obispos una especie de supervisión o «derecho de inspeccion" ${ }^{147}$.

Cabe agregar que «la posición del legislador respecto al culto pagano y sus ministros es de neta condena, pero más diluido es el modo de actuar en el tema de las fiestas, juegos, banquetes y otras tradiciones gentiles. No era ciertamente fácil obtener la supresión de diversiones arrraigadas en las costumbres populares; que, aunque tuvieran un origen religioso o mágico, progresivamente se fueron laicizando y ejercían una fascinación tal de atraer en algunos casos a las masas cristianas... Al contrario fueron permitidos los juegos en los cuales no era posible reconocer inmediatamente un significado religioso: como recuerda el Cod. Theod. XVI, 10, 3] $»^{148}$.

\section{CONCLUSIONES.}

Luego de la batalla de Frígido (394), Teodosio — convertido en el último emperador occidental en el trono de la pars orientalis, como también en el último que reino sobre todo el territorio occidental- se trasladó a Roma para organizar la administración de la ciudad y después a Milán, donde, debilitada su salud, convocó a su lado a su hijo Arcadio y a su hija Gala Placidia antes de

${ }^{145}$ CRACCO RUGGINI, Lellia, «Ambrogio e le apposizioni anticattoliche fra il 383 e il $390 \mathrm{~m}$, AUGUSTINIANUM, 14, dic. 1974, p. 419.

146 SINISCALCO, Paolo. Il cammino di Cristo nell'Impero Romano. Roma-Bari, Laterza, 1987, p. 218.

${ }^{147}$ Cfr. De GiovanNi, L. op. cit., P. 137/8.

148 Idem, p. 136.

Hispania, del Mediterráneo al Aulántico

Hispania Sacra 51 (1999) 
morir el 17 de enero del 395. Según Paribeni la ilusión imperial había durado solo cuatro meses» ${ }^{149}$.

Aunque mereciera otro trabajo no podemos dejar de hacer notar que Teodosio, pese a su indiscutido fe cristiana, no renegó de la teoría y práctica de la monarquía sagrada tradicional reelaborada por Eusebio de Cesarea, más allá de la relativa influencia latina ambrosiana. Como señala Cochrane «la santidad de la imperial persona venía supuesta en los prodigados títulos de sacratissimus princeps» ${ }^{150}$. Esta concepción fue rescatada por su contemporáneo Vegecio cuando escribía «al emperador, luego que ha sido declarado Augusto, se le debe amar y servir con anhelo, pues es la imagen de Dios sobre la Tierra ${ }^{151}$.

La ideología oficial del Imperio teodosiano consistía en un imperio romano-cristiano en el cual —como señalaba el poeta Prudencio- - «el nombre venerable de Cristo brilla sobre las armas» ${ }^{152}$. De este modo podemos vislumbrar que el nuevo Imperio permanecía «fiel a la creencia de los romanos de los primeros tiempos de la República, según la cual Roma dependía de la buena voluntad del poder divino»153. Una nueva mística estaba prendiendo ${ }^{154}$. Sin saberlo todavía sus dirigentes, Roma estaba salvada.

«Para Teodosio, la Iglesia había vencido definitivamente; él quería realizar, como soberano cristiano, el estado cristiano. La fe - liberada de las cadenas jurídicas y favorecida por todos los medios- debería ser no sólo el fermento de la sociedad, sino también el principio político que informara todo orden terreno. La política teodosiana tampoco escapó al peligro de identificar a Dios con la conservación del Estado y de las sociedad, en lugar de poner a la organización humana al servicio de Dios» ${ }^{155}$. Los mismos emperadores se convirtieron en parte de la Iglesia (Cfr. San Agustín. La Ciudad de Dios. V, 26), a la que antes perseguían.

«Desde el momento en que la Iglesia se había convertido en puntal de la autoridad estatal, cualquier amenaza a su unidad ponía también en peligro la solidez del edificio imperial. El cisma religioso podía provocar la guerra civil, o, al menos, la pérdida de la lealtad política de los súbditos imperiales no orto-

149 PARIBENe, R. op.cit., p. 176.

150 Cfr. COCHRANE, Ch. N. op. cit., p. $317 / 8$.

151 Epistoma rei militaris. II, 5.

152 Cit. FontaINE, J. «Le culte des martyrs militares et son expression poétique au IV siecle, l'idéall évangélique de la non-violence dans le christianisme, théodosien». en: Augustinianun. XX $1 / 2,1980$. p. 165.

I53 BARROW, Reginald. Los romanos. México, F.C.E., 1970, p. 189.

154 HUBENÁ, Florencio. Roma. El mito politico, espec. págs. 213/53.

155 MAIER, F, G. op. cit., p. 112. 
doxos» ${ }^{156}$. De este modo la defensa imperial adquiría otras características, la búsqueda de la unidad (la pax, la homonoia) ahora se hacía desde dentro de la Iglesia. Y era tarea fundamental del basileus buscar todos los caminos para la integración de herejes, paganos y «bárbaros» en el renacido Imperio, en la cristiandad.

Cochrane señala que «la consecuencia final del teodosianismo fue, sin duda, la cimentación de un nuevo orden europeo. Su efecto inmediato, sin embargo, fue precipitar la definitiva destrucción del antiguo» ${ }^{157}$. Nosotros, en cambio, coincidimos con Barrow cuando afirma que Roma no cayó nunca, sino que se transformó en otra cosa. Ya durante el reinado de Graciano cronistas como Lambese (Dessau II, S, 5520) hablaban de una aurea tempora o Verone (Dessau II, S, 5365) de la hortante beatitudine temporuz. Sin duda fue Teodosio quien, al lograr concretar las tentativas esbozadas por Constantino - aquel con ayuda de Eusebio de cesarea y éste de Dámaso de Roma y Ambrosio de Milán-, logró rescatar la relación política-religíón que tanto alabara Cicerón cuando afirmaba: «Nuestros antepasados nunca fueron más sabios ni estuvieron mejor inspirados por los dioses que cuando establecieron que las mismas personas presidieran la religión y gobernaran la República. Es por semejante medio como magistrados y pontífices cumplen sus cargos con sabiduría y juntos se entienden para salvar al estado»; creencia mistico-política que se encuentra -como demostrara Toynbee - en la base de toda civilización con futuro; en este caso el Imperio romano medieval. Teodosío al momento en que el imperio se desplomaba, aportó una pila de piedras a la construcción de la ciudad de, Dios» ${ }^{158}$.

\footnotetext{
156 Idem, p. 103.

157 COCHRANE, Ch. N. op. cit., p. 344.

158 PIGANIOL, A. op. cit., p. 221.
}

Hispania, del Mediterráneo al Atlántico Hispania Sacra 51 (1999) 